Review

\title{
Techniques for Analysis of Plant Phenolic Compounds
}

\author{
Ali Khoddami ${ }^{1}$, Meredith A. Wilkes ${ }^{1}$ and Thomas H. Roberts ${ }^{1, *}$ \\ Department of Plant and Food Sciences, University of Sydney, Sydney, NSW 2006, Australia; \\ E-Mails: ali.khoddami@sydney.edu.au (A.K.); meredith.wilkes@sydney.edu.au (M.A.W.) \\ * Author to whom correspondence should be addressed; E-Mail: thomas.roberts@sydney.edu.au; \\ Tel.: +61-2-8627-1042; Fax: +61-2-8627-1099.
}

Received: 25 October 2012; in revised form: 10 January 2013 / Accepted: 31 January 2013 / Published: 19 February 2013

\begin{abstract}
Phenolic compounds are well-known phytochemicals found in all plants. They consist of simple phenols, benzoic and cinnamic acid, coumarins, tannins, lignins, lignans and flavonoids. Substantial developments in research focused on the extraction, identification and quantification of phenolic compounds as medicinal and/or dietary molecules have occurred over the last 25 years. Organic solvent extraction is the main method used to extract phenolics. Chemical procedures are used to detect the presence of total phenolics, while spectrophotometric and chromatographic techniques are utilized to identify and quantify individual phenolic compounds. This review addresses the application of different methodologies utilized in the analysis of phenolic compounds in plant-based products, including recent technical developments in the quantification of phenolics.
\end{abstract}

Keywords: food analysis; phenolic compound; phenolic extraction technique; phenolic quantification method; HPLC; GC

\section{Introduction}

Plant foods are rich sources of phenolics, which are molecules that can act as antioxidants to prevent heart disease [1-3], reduce inflammation [4-6], lower the incidence of cancers [7-10] and diabetes [11,12], as well as reduce rates of mutagenesis in human cells $[7,13,14]$. The protection afforded by the consumption of plant products such as fruits, vegetables and legumes is mostly associated with the presence of phenolic compounds. 
Phenolic compounds are synthesized in plants partly as a response to ecological and physiological pressures such as pathogen and insect attack, UV radiation and wounding [15-18]. The basic structural feature of phenolic compounds is an aromatic ring bearing one or more hydroxyl groups (Figure 1) [19]. Plant phenolic compounds are classified as simple phenols or polyphenols based on the number of phenol units in the molecule. Thus, plant phenolics comprise simple phenols, coumarins, lignins, lignans, condensed and hydrolysable tannins, phenolic acids and flavonoids [20].

Figure 1. Basic structures of phenolic acids and flavonoids.

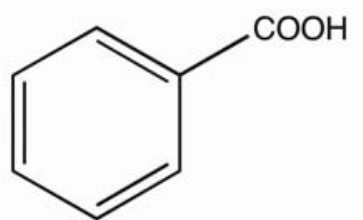

Hydroxybenzoic Acids

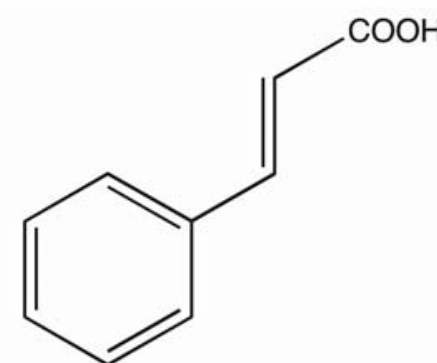

Hydroxycinnamic Acids

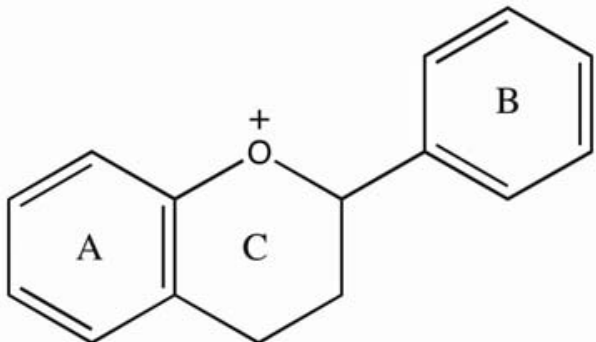

Flavonoids

Flavonoids are some of the most common phenolics, widely distributed in plant tissues, and often responsible alongside the carotenoids and chlorophylls for their blue, purple, yellow, orange and red colors. The flavonoid family includes flavones, flavonols, iso-flavonols, anthocyanins, anthocyanidins, proanthocyanidins and catechins [21,22]. All flavonoids are derived from the aromatic amino acids, phenyalanine and tyrosine, and have three-ringed structures [23]. Variation in flavonoid structure arises from the scale and pattern of hydroxylation, prenylation, alkalinization and glycosylation reactions that alter the basic molecule [24].

Phenolic acids are one of the other main phenolic classes within the Plant Kingdom and occur in the form of esters, glycosides or amides, but rarely in free form. Variation in phenolic acids is in the number and location of hydroxyl groups on the aromatic ring [25]. Phenolic acids have two parent structures: hydroxycinnamic and hydroxybenzoic acid. Hydroxycinnamic acid derivatives include ferulic, caffeic, $p$-coumaric and sinapic acids, while hydroxybenzoic acid derivatives consist of gallic, vanillic, syringic and protocatechuic acids.

Another major class of phenolic compounds is the cell wall phenolics. They are insoluble and found in complexes with other types of cell components. The two main groups of cell wall phenolics are lignins and hydroxycinnamic acids [26,27]. These compounds play a critical role in the cell wall during plant growth by protecting against stresses such as infection, wounding and UV radiation [28]. Tannins can be divided into two groups, hydrolysable tannins and condensed tannins, and have great potential to form oxidative linkages to other plant molecules.

Several recent reviews are available on the characterization of phenolics in foods [1,22-24,28]. Here we review several techniques to extract and analyse plant phenolic compounds. The most important steps for the analysis of phenolic compounds are sample preparation and extraction, followed by classification and quantification using spectrophotometry, gas chromatography (GC), high performance liquid chromatography (HPLC) or capillary electrophoresis (CE) methods. 


\section{Sample Preparation}

Plants foods (including fruits, cereal grains, legumes and vegetables) and beverages (including tea, coffee, fruit juices and cocoa) are major sources of phenolics in the human diet. The preparation and extraction of phenolic compounds from this wide range of samples depends mostly on the nature of the sample matrix and the chemical properties of the phenolics, including molecular structure, polarity, concentration, number of aromatic rings and hydroxyl groups. Variation in the chemistry of phenolics in a sample is related to the concentration of simple and complex polyphenolic compounds and the different proportions of phenolic acids, flavonoids, anthocyanins and proanthocyanins (among others). Thus, it is difficult to choose a single method of preparation and extraction for phenolics for many plant products.

Complexes with proteins, carbohydrates or other elements hinder complete extraction of some phenolics. For some preparation techniques, plant samples need to be dried using freeze-drying, air-drying or oven-drying. For example, Sejali and Anuar [29] indicated that higher amounts of phenolics can be extracted in shade air-dried neam leaf than from oven-dried samples. Dried samples are milled or ground to obtain a certain particle size, whereas liquid samples are treated by centrifugation, filtration and purification using a separation system when required. Higher extraction yields of phenolics are achieved by milling the sample into smaller particle sizes, thereby improving enzymatic action and extraction [30]. Defatting processes can be applied to remove oil from lipid-containing samples. For instance, Weidner et al. [31] defatted the ground seeds of grape to simplify phenolic extraction using hexane. In general, milling into small particle size (in combination with drying and de-fatting where appropriate) is advised for the most complete sample preparation prior to extraction.

\section{Overview of Phenolic Extraction}

Complete extraction of phenolic compounds is the next critical step after sample preparation. The most common techniques to extract phenolics employ solvents, either organic or inorganic. Several parameters may influence the yield of phenolics, including extraction time, temperature, solvent-to-sample ratio, the number of repeat extractions of the sample, as well as solvent type. Furthermore, the optimum recovery of phenolics is different from one sample to the other and relies on the type of plant and its active compounds. The choice of extraction solvents such as water, acetone, ethyl acetate, alcohols (methanol, ethanol and propanol) and their mixtures [32] will influence the yields of phenolics extracted. For instance, a high yield of phenolics can be extracted from sorghum leaf using water [33], while extraction of phenolics from wheat bran requires $80 \%$ aqueous ethanol [34]. In another example, an investigation into the effect of different solvents on extraction of phenolics from aerial parts of Potentilla atrosanguinea showed that $50 \%$ aqueous ethanol was more efficient than pure or $50 \%$ aqueous forms of methanol, and acetone [35]. In contrast, the highest levels of phenolics are extracted from Vitis vinifera wastes and sunflower meal using pure methanol and $80 \%$ aqueous acetone, respectively [36,37]. These differences could be due to the properties of the phenolic components of the plants concerned.

In addition to selecting the optimal extraction solvent, there are two other important parameters that affect the yield of phenolics extracted from plant foods: time and temperature. Normally, increasing 
time and temperature promote analyte solubility; however, plant phenolics are generally degraded or undergo undesirable reactions such as enzymatic oxidation by extended extraction times and high temperatures [38,39]. Naczk et al. [40] demonstrated that the optimum extraction time and temperature to extract phenolics from canola meal is $2 \mathrm{~min}(2 \times 1 \mathrm{~min})$ at room temperature. The solvent-to-sample ratio and the number of replicate extractions performed for each sample also affect the recovery of phenolics. Increasing the solvent-to-sample ratio promotes phenolic extraction from plant samples but determining the optimum ratio is advisable so that solvent input and saturation effects of solvent by the phenolics are minimized. Al-Farsi and Lee [41] reported that a 60:1 ratio of solvent to sample in a two-stage procedure is sufficient to extract most phenolics from plant tissues.

Sample matrix and particle size also strongly influence phenolic extraction from plant materials. Phenolics may bind to other sample elements such as carbohydrates and proteins [42]. These linkages can be hydrolyzed by addition of enzymes, thereby promoting the release of bound phenolics [42]. Acidic and alkaline hydrolysis are also employed in the isolation of phenolics from plants and plant products and are important for the stability of the phenolics in the extract [43,44]. Flavonoid aglycones have been identified by acidic hydrolysis of the glycosidic residues bound to the flavonoid nucleii in 20 plant sources [43]. In another study, Davidov-Pardo et al. [39] reported that a $\mathrm{pH}$ of 4-5 was associated with greater stability of catechins and their isomers than alkaline and more acidic conditions. General considerations/techniques for extraction of specific classes of phenolic compounds will be discussed in more detail in the following sections.

\subsection{Phenolic Acid Extraction}

Phenolic acids generally exist in a free, esterified or glycosylated form in plants. Ayumi et al. [45] extracted free phenolic acids in rice using $70 \%$ ethanol at room temperature followed by centrifugation. The extract was then treated with $4 \mathrm{M} \mathrm{HCl}$ to reduce the $\mathrm{pH}$ to 2-3 and the phenolic fraction separated using ethyl acetate and dried with anhydrous disodium sulfate. The bound or esterified phenolic acids of rice were extracted by removing the free phenolic acids and lipid using $70 \%$ ethanol and hexane, respectively. The dried ethyl acetate fractions were treated with $1 \mathrm{M} \mathrm{NaOH}$ containing $0.5 \%$ sodium borohydride $\left(\mathrm{NaBH}_{4}\right)$ to liberate esterified phenolic acids in a stream of $\mathrm{N}_{2}$ gas, followed by centrifugation to obtain a clear supernatant. Degradation of phenolic acids during alkaline hydrolysis can be prevented by adding EDTA or ascorbic acid [46].

Free, esterified and glycosylated phenolic acids have been separated from wheat, rye and triticale [47]. Phenolic compounds were extracted using $80 \%$ methanol for $15 \mathrm{~min}$ at $80{ }^{\circ} \mathrm{C}$ and the extract concentrated by evaporating the organic solvent. An aqueous suspension of the extract was then prepared and adjusted to $\mathrm{pH} 2$ with $6 \mathrm{M} \mathrm{HCl}$ and the free phenolic acids extracted using diethyl ether. The residue of the suspended extract was neutralized and dissolved in $20 \mathrm{~mL}$ of $\mathrm{NaOH}(2 \mathrm{M})$ for $4 \mathrm{~h}$ under $\mathrm{N}_{2}$. After alkaline hydrolysis, the extract was acidified again to $\mathrm{pH} 2$. Esterified phenolic acids, derivatized by mixing the extract with diethyl ether, were isolated using a separating funnel. To release phenolic acids from glycosylated forms, $15 \mathrm{~mL}$ of $6 \mathrm{M} \mathrm{HCl}$ was added to the remaining aqueous fraction and the mixture kept in $100{ }^{\circ} \mathrm{C}$ for $1 \mathrm{~h}$ under $\mathrm{N}_{2}$. Finally, the released phenolic acids were isolated using diethyl ether. Apart from ethanol, mixtures of water with methanol, acetone and 
chloroform may be used for phenolic acid extraction from plant-based products [24]. These studies show that free and bound forms of phenolic acids can be extracted sequentially from plant samples.

\subsection{Flavonoid Extraction}

Flavonoids are highly bioactive compounds found in both edible and non-edible plants. They are often extracted with methanol, ethanol, acetone, water or mixtures of these solvents using heated reflux extraction methods [23,48-50]. Following extraction, the flavonoid glycosides are frequently hydrolyzed into the aglycone forms by applying $\mathrm{HCl}$ under $\mathrm{N}_{2}$. Haghi and Hatami [43] extracted flavonoids from different types of herbal plant materials with $50 \%$ methanol acidified by $1.2 \mathrm{M} \mathrm{HCl}$. Ascorbic acid was added to prevent oxidation of the mixture. The hydrolysis of the flavonoid glycosides was carried out for $2 \mathrm{~h}$ at $80{ }^{\circ} \mathrm{C}$ [43]. Tsimogiannis et al. [51] extracted flavonoids from dried and defatted plant material in diethyl ether and filtered pooled samples for HPLC analysis. Flavonoids can also be extracted from plant material with $62.5 \%$ methanol. The extract is acidified with $6 \mathrm{M} \mathrm{HCl}$ under $\mathrm{N}_{2}$ at $90{ }^{\circ} \mathrm{C}$ for $2 \mathrm{~h}$ to obtain flavonoid glycones [52]. Wu et al. [53] focused on optimization of enzymatic extraction of flavonoids from celery stalks. The pulpy aqueous homogenate was mixed with $1 \mathrm{~N} \mathrm{HCl}$ or $\mathrm{NaOH}$ to adjust the $\mathrm{pH}$ and the mixture incubated at the desired temperature. A complex mixture of enzymes was added to the sample under stirring at $150 \mathrm{rpm}$. The enzymes were then inactivated by heating at $90{ }^{\circ} \mathrm{C}$ for $10 \mathrm{~min}$ and the supernatant of the centrifuged mixture was collected for total flavonoid determination.

Biesaga [50] extracted flavonoids in maize samples using heated reflux, microwave-assisted extraction (MAE), ultrasonic-assisted extraction (UAE) and maceration and compared the stability of the extracted compounds. The highest stability of the extracted flavonoids in methanol-water $(60: 40 \mathrm{v} / \mathrm{v})$ was for compounds extracted with traditional heated reflux in a water bath and MAE within 1 min under $160 \mathrm{~W}$.

\subsection{Anthocyanin/Proanthocyanidin Extraction}

Anthocyanins are the most common pigments in nature and can be extracted with acidified solvents like water, acetone, ethanol, methanol or mixtures of aqueous solvents [54-57]. The acid in the solvents acts to rupture cell membranes and release anthocyanins; however, this harsh chemical treatment may break down the innate anthocyanin structure. It is therefore important to acidify solvents with organic acids (formic or acetic acid) rather than mineral acids such as $0.1 \% \mathrm{HCl}$ [58]. Bridgers et al. [59] reported that extraction of anthocyanin from purple-fleshed sweet potato was more effective with acidified methanol and ethanol than non-acidified solvents. According to Awika et al. [56], the extraction of anthocyanin from black sorghum with acidified methanol was significantly higher than with aqueous acetone. This result is in agreement with Lee et al. [60], who used the same solvents to extract anthocyanin from three American Vaccinium species.

Methanol is indeed the most common and effective solvent for extracting anthocyanins; however, it is an environmental pollutant and more toxic than other alcohols [59,61]. Thus ethanol is preferred for the recovery of anthocyanins from plant material to use as natural colorants or nutraceuticals [62]. Apart from acidified solvent extraction, sulfur water (aqueous $\mathrm{SO}_{2}$ ) has also been used to extract anthocyanins from plant materials such as red grape skin and black currants $[63,64]$. 
Proanthocyanidins are a group of polymerized polyphenols commonly referred to as condensed tannins [65]. They are found naturally in grape seed and skin, malt, apple juice, cider, mangosteen pericarp, hops, berries, pine bark, chocolate, sorghum and sea bark [65,66]. For proanthocyanidin extraction, organic solvents are usually used, including ethanol as well as methanol and acetone [67,68]. For example, Hernández-Jiménez et al. [67] reported that ethanol is the best solvent for proanthocyanidin extraction from grape seed. Ionic liquids (molten salts), which are chemically stable, easily recycled and non-flammable, are a new alternative solvent for extracting proanthocyanidins. They have been used to extract proanthocyanidins from Larix gmelini bark using microwave-assisted extraction methods, resulting in higher yields of proanthocyanidin when compared to conventional extraction methods with organic solvents [69].

\section{Modern Extraction Techniques for Phenolics}

Sample preparation and removal of unwanted substances for accurate quantification of phenolics is important, but the extraction procedure is the primary determinant for the separation and recovery of phenolics. As mentioned earlier, extraction is generally influenced by the sample nature, particle size, solvent type as well as extraction techniques employed.

Soxhlet, heated reflux extraction and maceration are conventional procedures frequently used to recover phenolics from solid samples. The Soxhlet and heated reflux methods are normally performed at $90{ }^{\circ} \mathrm{C}$ for several hours while maceration is performed over days at ambient temperature. These methods are simple, require relatively cheap apparatus and result in adequately high phenolic extraction rates $[35,50,70]$. Castro-Vargasa et al. [70] reported that the highest total phenolic content of Guava seed extract was achieved using Soxhlet extraction techniques. In another study, phenolic compounds from seeds of three wild grapevines were successfully extracted using the Soxhlet technique [31]. While there are many positive aspects of this method, there are substantial disadvantages, including: (1) the need to use large volumes of hazardous organic solvents, which are environmental pollutants and health hazards; (2) long extraction times and (3) interference with, and degradation of, targeted components due to both internal and external factors such as light, air, high temperatures and enzymatic reactions [71-73].

Soxetec is a modified Soxhlet extraction method. The advantages of this technique over normal Soxhlet or heated reflux systems are a low consumption of organic solvents and shorter extraction times, as well as the ability to recycle solvents [74]. Maceration has the same disadvantages as other conventional extraction methods, and is characterized by low efficiency of phenolic extractions $[35,75]$. Due to problems associated with conventional extraction procedures, a demand for alternative techniques for extraction of phenolic compounds has arisen. The use of ultrasound-assisted extraction (UAE), microwave-assisted extraction (MAE), ultrasound-microwave-assisted extraction (UMAE), supercritical fluid extraction (SFE), sub-critical water extraction (SCWE) and high hydrostatic pressure processing (HHPP) is increasing. These methods shorten extraction times, decrease the release of toxic pollutants through reducing organic solvent consumption, and are relatively simple to perform. 


\subsection{Ultrasound-Assisted Extraction (UAE)}

Ultrasonic radiation, which has frequencies higher than $20 \mathrm{kHz}$, facilitates the extraction of organic and inorganic compounds from solid matrices using liquid solvents. Sonication is the production of sound waves that create cavitation bubbles near the sample tissue, which break down to disrupt cell walls, thereby releasing cell contents [76,77]. An appropriate solvent is mixed with a sample and sonicated under controlled temperature for a specified time. Extract recovery is influenced not only by sonication time, temperature and solvent selection, but also by wave frequency and ultrasonic wave distribution [78]. Ultrasound has been used in both static and dynamic modes to extract phenolics from plant materials [79]. A static system is a closed-vessel extraction for which no continuous transfer of solvent occurs. In dynamic extraction, fresh solvent is supplied continuously, which allows efficient adsorption of analytes and their effective transfer from the extraction vessel. Continuous transfer of extracted analytes prevents degradation of any thermo-labile compounds by the heat associated with sonication [80-82].

Probe and bath systems are the two most common ways of applying ultrasound waves to the sample. Probe sonicators are constantly in contact with the sample and make reproducibility and repeatability difficult. In addition, the risk of sample contamination and foam production is higher. Bath sonicators can act on a range of samples simultaneously and allow for higher reproducibility [83].

Compared to conventional methods, UAE is one of the most simple, inexpensive extraction systems and can be operated rapidly in a broad range of solvents for large-scale preparations suited for industrial purposes [84]. As a method to extract phenolic compounds from Potentilla atrosanguinea and Pinus radiata, UAE has been shown to be more effective than maceration but less effective than heated reflux, MAE and UMAE methods [35]. Many studies have involved extraction of biologically active compounds from different types of samples using these techniques (Table 1).

Table 1. Extraction of biologically active compounds using UAE.

\begin{tabular}{|c|c|c|c|c|c|}
\hline Sample & Solvent & $\begin{array}{l}\text { Extraction } \\
\text { time (min) }\end{array}$ & Phenolic class & $\begin{array}{c}\text { Yield } \\
\left(\mathrm{mg} \mathrm{GAE}^{\mathrm{b}} / \mathrm{g}\right)\end{array}$ & Reference \\
\hline $\begin{array}{c}\text { Puerariae lobatae } \\
\text { radix }\end{array}$ & Ethanol $80 \%$ & 55 & Isoflavones & 128 & {$[53]$} \\
\hline Vitis vinifera & Methanol & 60 & $\begin{array}{l}\mathrm{TPC}^{\mathrm{a}} \text { and } \\
\text { flavonoid }\end{array}$ & 55.90 & {$[36]$} \\
\hline Galla chinensis & Ethanol 70\% & 40 & Tannin & 491.2 & {$[85]$} \\
\hline Sunflower meal & Acetone $80 \%$ & 30 & $\mathrm{TPC}^{\mathrm{a}}$ & 30.93 & [37] \\
\hline Orange peel & Ethanol $80 \%$ & 30 & $\mathrm{TPC}^{\mathrm{a}}$ & 2.758 & {$[86]$} \\
\hline $\begin{array}{c}\text { Satsuma mandarin } \\
\text { peel }\end{array}$ & Methanol 80\% & 60 & Hesperidine & 1.446 & {$[87]$} \\
\hline $\begin{array}{c}\text { Aerial parts of } \\
\text { Potentilla } \\
\text { atrosanguinea }\end{array}$ & Ethanol $50 \%$ & 60 & $\mathrm{TPC}^{\mathrm{a}}$ & 27.80 & [35] \\
\hline Soy beans & Ethanol $40-60 \%$ & 20 & Isoflavones & 1.353 & [88] \\
\hline
\end{tabular}

${ }^{\mathrm{a}}$ Total phenolic content; ${ }^{\mathrm{b}}$ Gallic acid equivalent. 


\subsection{Microwave-Assisted Extraction (MAE)}

Microwaves have been applied widely in research on secondary plant metabolites for decades [89]. Microwaves are non-ionizing radiation with wavelengths ranging from as long as one meter to as short as one millimeter (frequencies between $300 \mathrm{MHz}$ and $300 \mathrm{GHz}$ ). Microwaves induce molecular motion in materials or solvents with dipoles, resulting in sample heating [90]. The heating causes plant cells to lose moisture through evaporation; the steam generated swells and eventually ruptures the cells, releasing their active components [78]. Apart from dipole materials of the plant cell, such as water molecules, the dipole rotation of the solvent molecules under the rapid change of electric field plays an important role in MAE. During radiation, the wave electronic module changes $4.9 \times 10^{4}$ times/s and the solvent molecules are induced to align themselves in the normal phase with the electric field. At such a great change in the speed of the electric phase the solvent molecules fail to realign and begin to vibrate, heating the sample due to frictional forces [91].

The advantages of MAE techniques compared to conventional methods (such as maceration and heat reflux) include reduced use of organic solvents, reduced extraction time (generally less than $30 \mathrm{~min}$ ) and increased extraction yields [92].

The hot solvents generated in MAE penetrate easily into the matrix and extract compounds from the lysed plant cells. For thermolabile samples, transparent solvents such as hexane, chloroform and toluene, or mixtures with non-transparent solvents, prevent degradation. It is important to select suitable solvents based on their boiling points, dissipation and dielectric properties [93]. The most commonly applied solvents in MAE are presented in Table 2. Polar solvents have a higher dielectric constant than non-polar solvents and can absorb more microwave energy, which can result in a higher yield of phenolics.

Table 2. Important properties of some solvents commonly used in MAE.

\begin{tabular}{ccccc}
\hline Solvent & Formula & Boiling point $\left({ }^{\circ} \mathbf{C}\right)$ & Dielectric constant $^{\text {a }}$ & Dissipation factor \\
\hline Acetonitrile & $\mathrm{C}_{2} \mathrm{H}_{3} \mathrm{~N}$ & 81.60 & 37.50 & 620 \\
Water & $\mathrm{H}_{2} \mathrm{O}$ & 100 & 78.30 & 1570 \\
Ethanol & $\mathrm{C}_{4} \mathrm{H}_{8} \mathrm{O}_{2}$ & 78.5 & 24.30 & 2500 \\
Acetone & $\mathrm{C}_{3} \mathrm{H}_{6} \mathrm{O}$ & 56.2 & 20.70 & 5555 \\
Methanol & $\mathrm{CH}_{4} \mathrm{O}$ & 64.6 & 32.60 & 6400 \\
2-Propanol & $\mathrm{C}_{4} \mathrm{H}_{8} \mathrm{O}$ & 98 & 19.90 & 6700 \\
\hline
\end{tabular}

${ }^{\text {a }}$ Determined at $20^{\circ} \mathrm{C}[94,95]$.

The dissipation factor is also important to illustrate the solvent's power to release absorbed energy as heat to the sample material. Polyphenols are dipoles that can absorb microwave energy due to their hydroxyl groups; therefore MAE is a technique that can be used for the extraction of these compounds [96,97]. Aqueous acetone, ethanol, or their mixtures are employed to extract phenolic compounds using MAE [93]. As MAE is influenced by many factors, several statistical optimizations have been performed to determine the best operating conditions to extract different phenolics [95,98].

Xiao et al. [99] evaluated all the influential parameters mentioned above to extract flavonoids from Radix astragali. The selected conditions were 60-100\% v/v aqueous ethanol, 10-40 mL solvent per $\mathrm{g}$ 
material, 5-30 min irradiation, 70-130 ${ }^{\circ} \mathrm{C}$ and $200-1000 \mathrm{~W}$ microwave power. The most effective extraction was achieved by applying $25 \mathrm{~mL}$ of $90 \%$ ethanol for $25 \mathrm{~min}$ at $110^{\circ} \mathrm{C}$ under $1,000 \mathrm{~W}$.

In other research, the effects of temperature, ethanol composition and time on the percent recovery of the anthraquinones extracted from Morinda citrifolia by MAE were determined [100]. The results revealed that MAE has the power to give the highest yield compared to other methods. The reported appropriate MAE conditions were $80 \%$ aqueous ethanol at a temperature of $60{ }^{\circ} \mathrm{C}$ for $30 \mathrm{~min}$.

The above-mentioned results demonstrate the potential for new MAE methods to extract phenolic compounds from plant material when compared with other extraction method such as maceration, UAE and Soxhlet. Table 3 summarizes some other research on optimization of phenolic extraction using MAE.

Table 3. Optimized conditions for phenolic extraction from plant-based foods using MAE.

\begin{tabular}{|c|c|c|c|c|c|c|c|}
\hline Sample & Analyte & Solvent & $\begin{array}{c}\text { MAE } \\
\text { time } \\
(\mathrm{min})\end{array}$ & $\begin{array}{c}\text { MAE } \\
\text { temperature } \\
\left({ }^{\circ} \mathrm{C}\right) \\
\end{array}$ & $\begin{array}{c}\text { MAE } \\
\text { power } \\
(\mathbf{W})\end{array}$ & $\begin{array}{l}\text { Solvent/ } \\
\text { sample } \\
(\mathrm{mL} / \mathrm{g}) \\
\end{array}$ & Reference \\
\hline Green Tea & Flavanol & Water & 30 & 80 & 600 & 20 & [101] \\
\hline Tea & Polyphenols & Ethanol $60 \%$ & 10 & 80 & 600 & 12 & [102] \\
\hline $\begin{array}{c}\text { Ipomoea } \\
\text { batatas }\end{array}$ & $\mathrm{TPC}^{\mathrm{a}}$ & Ethanol 53\% & 2.05 & -- & 302 & 30 & [103] \\
\hline $\begin{array}{c}\text { Phaseolus } \\
\text { vulgaris }\end{array}$ & $\mathrm{TPC}^{\mathrm{a}}$ & Ethanol $50 \%$ & 15 & 150 & -- & 49 & [104] \\
\hline $\begin{array}{l}\text { Fagopyrum } \\
\text { esculentum }\end{array}$ & $\mathrm{TPC}^{\mathrm{a}}$ & Ethanol $50 \%$ & 15 & 150 & -- & 50 & [105] \\
\hline $\begin{array}{c}\text { Visit } \\
\text { vinifera }\end{array}$ & $\begin{array}{c}\mathrm{TPC}^{\mathrm{a}} \\
\text { Flavonoids }\end{array}$ & $\begin{array}{c}\text { Methanol } \\
100 \%\end{array}$ & 60 & 110 & 60 & 5 & [36] \\
\hline $\begin{array}{l}\text { Melilotus } \\
\text { officinalis } \\
\quad \text { (L.) }\end{array}$ & Coumarin & Ethanol $50 \%$ & 5 & 50 & 100 & 20 & [106] \\
\hline $\begin{array}{l}\text { Vanilla } \\
\text { beans }\end{array}$ & Vanillin & Ethanol $70 \%$ & 20 & -- & 150 & 25 & [107] \\
\hline $\begin{array}{c}\text { Radix } \\
\text { angelicae } \\
\text { sinensis }\end{array}$ & Ferulic acid & Ethanol 90\% & 9 & -- & 850 & 6 & [108] \\
\hline $\begin{array}{l}\text { Saussurea } \\
\text { medusa }\end{array}$ & Flavonoids & Ethanol $80 \%$ & 60 & 80 & 1200 & 50 & [109] \\
\hline Sorghum & $\begin{array}{l}\text { Phenolic } \\
\text { acids }\end{array}$ & $2 \mathrm{M} \mathrm{NaOH}$ & 0.45 & 190 & 1400 & 25 & [110] \\
\hline Spices & $\begin{array}{c}\text { Phenolic } \\
\text { acids }\end{array}$ & Ethanol $50 \%$ & 18 & 50 & 200 & 20 & [111] \\
\hline
\end{tabular}

${ }^{\mathrm{a}}$ Total phenolic content. 


\subsection{Ultrasound/Microwave Assisted Extraction (UMAE)}

The coupling of two powerful radiation techniques (ultrasonic and microwave) is a new efficient approach to extract bioactive compounds. As mentioned earlier, MAE is a simple and rapid technique using dielectric mechanisms to heat samples and extract the plant bioactive compounds [92], whereas UAE forms cavitations, which increase mass transfer and improve penetration of the solvent into the sample [112]. Thus, ultrasound/microwave-assisted extraction (UMAE) is a powerful technique that can reduce extraction time, consume lower volumes of solvents and result in higher extraction yields than conventional extraction, MAE and UAE [113].

Lou et al. [114] applied microwaves with ultrasonic extraction (UAME) and maceration to extract phenolics from Burdock leaves. The final optimized UMAE method gave a phenolic yield of $9 \mathrm{mg} / \mathrm{g}$ while less than $0.5 \mathrm{mg} / \mathrm{g}$ was achieved using maceration.

In another study, the yields of flavonoids from Spatholobus suberectus obtained by UMAE were compared with MAE, UAE, Soxhlet and heated reflux extraction methods under optimized conditions. The highest yield obtained for UAME was after $7.5 \mathrm{~min}$ using $20 \mathrm{~mL} / \mathrm{g}$ solvent-sample ratio, while for other extractions, optimum yields depended on a higher solvent-sample ratio $(40-120 \mathrm{~mL} / \mathrm{g})$ and longer time (30-3,600 $\mathrm{min})$ [115].

Tomato paste lycopene has been extracted using UMAE and UAE. The optimized time needed to give the highest yield of extract $(97.4 \%$ lycopene) with UMAE was 367 seconds, whereas the corresponding time for UAE was 1,746 seconds and gave a lower yield (89.4\% lycopene) [116]. These results above imply that UMAE is a more efficient extraction method than the other extraction techniques tested. A schematic diagram of an apparatus for UMAE is presented in Figure 2 [115].

Figure 2. Schematic diagram of an apparatus for ultrasonic-microwave assisted extraction (UMAE) [115].

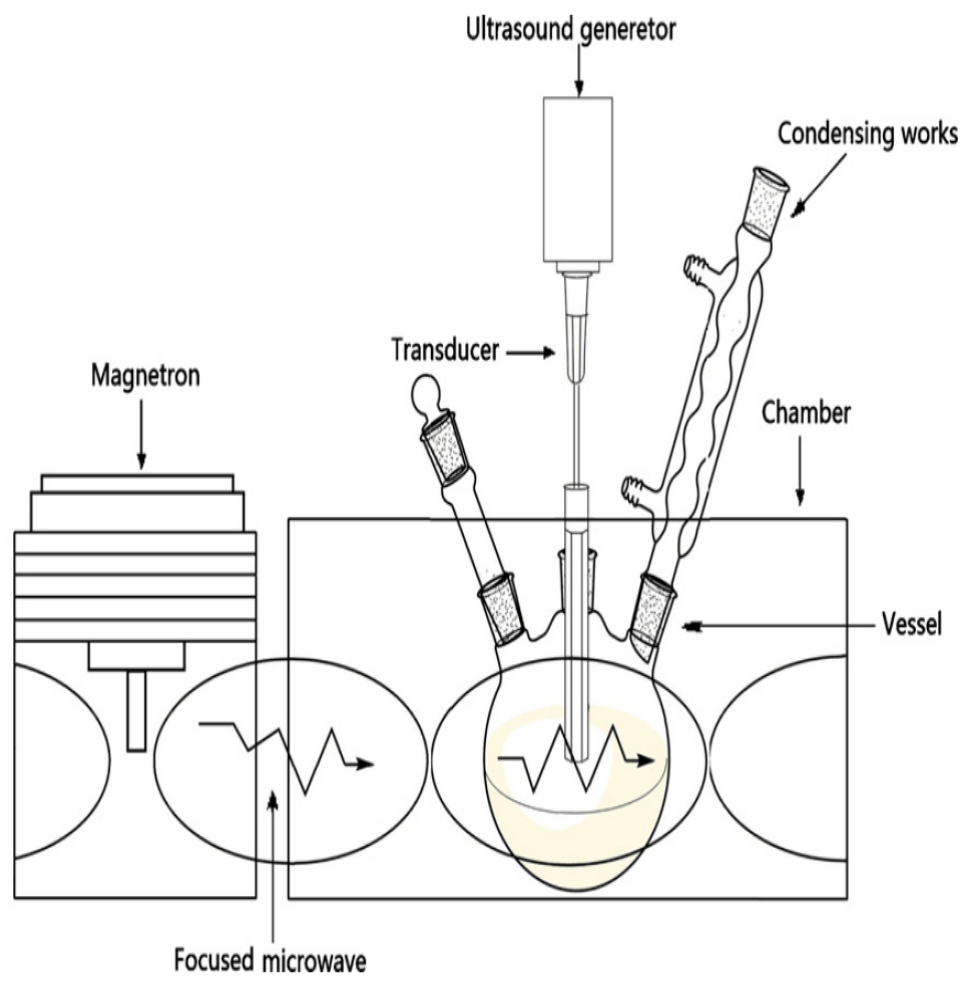


Table 4 summarizes results using optimized UMAE to extract bioactive compounds from plant materials.

Table 4. Conditions for phenolic extraction from plant-based foods using UMAE.

\begin{tabular}{|c|c|c|c|c|c|c|c|c|}
\hline Sample & Analyte & Solvent & $\begin{array}{l}\text { Ultrasound } \\
\text { power (W) }\end{array}$ & $\begin{array}{l}\text { Microwave } \\
\text { power (W) }\end{array}$ & $\begin{array}{l}\text { UMAE } \\
\text { time (s) }\end{array}$ & $\begin{array}{c}\text { UMAE } \\
\text { temp } \\
\left({ }^{\circ} \mathbf{C}\right) \\
\end{array}$ & $\begin{array}{r}\text { Solvent/ } \\
\text { sample } \\
(\mathrm{mL} / \mathrm{g})\end{array}$ & Ref. \\
\hline $\begin{array}{c}\text { Arctium } \\
\text { lappa }\end{array}$ & Caffeic acid & $\begin{array}{c}\text { Ionic } \\
\text { solution }\end{array}$ & 50 & 400 & 30 & -- & 20 & [117] \\
\hline $\begin{array}{l}\text { Spatholobus } \\
\text { suberectus }\end{array}$ & Flavonoids & $\begin{array}{c}\text { Methanol } \\
70 \%\end{array}$ & 50 & 300 & 450 & 80 & 20 & [115] \\
\hline Tomato & Lycopene & $\begin{array}{l}\text { Ethyl } \\
\text { acetate }\end{array}$ & 50 & 98 & 367 & -- & 10.6 & [116] \\
\hline $\begin{array}{l}\text { Burdock } \\
\text { leaves }\end{array}$ & $\begin{array}{c}\text { Phenoliccom } \\
\text { pounds }\end{array}$ & $\begin{array}{c}\text { Ethanol } \\
70 \%\end{array}$ & 50 & 500 & 30 & -- & 20 & [114] \\
\hline $\begin{array}{c}\text { Anoectochilu } \\
\text { roxburghii }\end{array}$ & Quercetin & $\begin{array}{c}\text { Ethanol } \\
50 \%\end{array}$ & 50 & 800 & 900 & 45 & 8 & [118] \\
\hline
\end{tabular}

\subsection{Supercritical Fluid Extraction (SFE)}

Supercritical fluid extraction (SFE) is another environmentally friendly extraction technique, which can be a good alternative to conventional organic solvent extraction methods [1]. It may lower the requirement for toxic organic solvents, increase safety and selectivity, lower extraction time and facilitate separation of the extract from the supercritical fluids (SCF). Furthermore, degradation of extracted compounds can be avoided in the absence of air and light and the possibility of contaminating the sample with solvent impurities is much lower than in other methods $[119,120]$. The high capital investment for equipment is the main disadvantage of SFE.

A SCF is a type of solvent that forms when the temperature and pressure of the fluid increase above its critical point [120]. The SCF generated has the penetration power of the gas form and density of the liquid form [96,121]. The usual SCF applied in SFE are methane, carbon dioxide, ethane, propane, ammonia, ethanol, benzene and water. Table 5 illustrates the critical temperature (Tc) and a pressure (Pc) of some SCFs.

Table 5. Critical properties of commonly used SCFs.

\begin{tabular}{cccc}
\hline Solvent & Pc (bar) & Tc $\left({ }^{\circ} \mathbf{C}\right)$ & Density $(\mathbf{g} / \mathbf{m L})$ \\
\hline Methane & 46.41 & -82.4 & 0.16 \\
Carbon dioxide & 73.87 & 31.2 & 0.47 \\
Ethane & 48.84 & 32.5 & 0.20 \\
Propane & 42.46 & 97.3 & 0.22 \\
Ammonia & 113.99 & 132.6 & 0.24 \\
Ethanol & 63.83 & 243.6 & 0.28 \\
Benzene & 48.94 & 289.1 & 0.30 \\
Water & 221.19 & 374.3 & 0.32 \\
\hline
\end{tabular}


$\mathrm{CO}_{2}$ is the most commonly utilized SCF in SFE. It is chemically stable, has relatively low toxicity, is not flammable, is inexpensive and produces zero surface tension [122]. Furthermore, it has a mild critical temperature required for extraction of thermolabile compounds and is separated easily from the sample [123]. However, $\mathrm{CO}_{2}$ is non-polar and thus unsuitable for extraction of polar phenolic compounds. To cover this weakness and boost $\mathrm{CO}_{2}$ extraction power, the addition of polar co-solvents such as ethanol, methanol, ethyl acetate and acetone is recommended [119]. In the last decade, research has been conducted to optimize the extraction of phenolic compounds by SFE by varying pressure, temperature, extraction time, modifier and the solvent/ modifier mixture ratio [74,124,125]. For most phenolic materials, the highest yield was attained when the pressure was 50-600 bar, temperature 35-20 ${ }^{\circ} \mathrm{C}$ and time 5-180 $\min [126]$.

Different extraction methods including Soxhlet, MAE and UAE, as well as SFE, have been applied to determine total phenolic content of pomegranate seed oil. The different organic solvent extraction methods used in this study did not generate any significant differences in the total phenolics extracted, whereas the extracted oils from modified SFE gave a significantly higher yield of phenolic compounds [124]. In a study on oat bran, Holliday [127] reported that total phenolic content and antioxidant activity obtained under SFE conditions was higher than with MAE and conventional solvent extraction. However, the opposite was found for the amount of phenolics detected in the SFE extract [102]. The difference between SFE and MAE, as two of the more accepted techniques, may be due to different extraction times and temperatures, and the presence or absence of modifier solvent. Table 6 summarizes SFE conditions for extraction of phenolic compounds from some plant-based samples.

Table 6. SFE conditions for extraction of phenolic compounds from plant-based samples.

\begin{tabular}{|c|c|c|c|c|c|c|}
\hline Sample & $\begin{array}{c}\text { Target } \\
\text { phenolic class }\end{array}$ & $\begin{array}{c}\text { Temperature } \\
\left({ }^{\circ} \mathrm{C}\right) \\
\end{array}$ & $\begin{array}{l}\text { Time } \\
(\mathrm{min})\end{array}$ & $\begin{array}{c}\text { Pressure } \\
\text { (bar) }\end{array}$ & Modifier & Ref. \\
\hline $\begin{array}{l}\text { Elder berry and } \\
\text { grape marc }\end{array}$ & $\begin{array}{l}\text { Phenolic } \\
\text { compounds }\end{array}$ & 40 & -- & 150,350 & Ethanol & {$[68]$} \\
\hline $\begin{array}{l}\text { Theobroma } \\
\text { cacao hulls }\end{array}$ & $\begin{array}{l}\text { Phenolic } \\
\text { compounds }\end{array}$ & 50 & -- & 100,200 & $\begin{array}{c}\text { Methanol } \\
\text { and Acetone }\end{array}$ & [128] \\
\hline Sweet basil & $\begin{array}{l}\text { Phenolic } \\
\text { compounds }\end{array}$ & 35,50 & $\begin{array}{c}15,30,45 \\
60\end{array}$ & $\begin{array}{c}100,150,200 \\
250,300\end{array}$ & $\mathrm{H}_{2} \mathrm{O}$ & [129] \\
\hline $\begin{array}{c}\text { Baccharis } \\
\text { dracunculifolia } \\
\text { leaves }\end{array}$ & $\begin{array}{l}\text { Phenolic } \\
\text { compounds }\end{array}$ & $40,50,60$ & -- & $200,300,400$ & -- & [130] \\
\hline Guava seed & Phenolic content & $40,50,60$ & 120 & $100,200,300$ & $\begin{array}{l}\text { Ethylacetate } \\
\text { and Ethanol }\end{array}$ & {$[70]$} \\
\hline Wheat germ & Phenolic content & 40,60 & 10,60 & 148,602 & -- & [125] \\
\hline Pistachio hulls & Phenolic content & $35,45,55$ & $15,25,40$ & $100,200,350$ & Methanol & [131] \\
\hline Bupleurum roots & Phenolic content & 40 & -- & $\begin{array}{c}50,100,150 \\
200\end{array}$ & -- & [132] \\
\hline Bitter melon & Flavonoids & $30,40,50$ & $40,50,60$ & $250,300,350$ & Ethanol & [133] \\
\hline Spearmint leaves & Flavonoids & $40,50,60$ & $30,60,90$ & $100,200,300$ & Ethanol & [134] \\
\hline Pecah Kaca & Flavonoids & $40,50,60$ & $40,60,80$ & $100,150,200$ & Ethanol & [135] \\
\hline Pueraria lobata & Flavonoids & $40,50,60$ & 90 & $150,200,250$ & Ethanol & [136] \\
\hline
\end{tabular}




\subsection{Subcritical Water Extraction (SCWE)}

Another environmentally friendly extraction technique that has been utilized to efficiently isolate phenolic compounds is subcritical water extraction (SCWE) [137,138], also known as superheated water, pressurized water or hot liquid water extraction. The main advantages of SCWE over conventional methods are its simplicity, high extract quality, low extraction time and environmental friendliness due to water being used as the solvent [138]. With SFE, only non-polar compounds can be extracted from plant material using organic solvents as modifiers, and plant processing is likely to be more expensive than with SCWE [138].

Water becomes subcritical when the temperature is $100-347{ }^{\circ} \mathrm{C}$ applied under sufficient pressure (normally 10-60 bar) to preserve its liquid form (below 220 Bar) [139]. The dielectric constant of water reduces under subcritical conditions due to the breakdown of intermolecular hydrogen bonds. By adjusting parameters like pressure and temperature, subcritical water displays different dielectric constant values and polarity (i.e., ethanol-water and methanol-water) [9,140]. Water at room temperature has high polarity and a dielectric constant close to 80 . By applying suitable pressure to keep water in liquid form at $250^{\circ} \mathrm{C}$, the dielectric constant decreases to 27 , which is similar to that of ethanol [141].

Treatment with SCWE has been shown to be sufficiently powerful to extract a wide range of polar to low-polar compounds such as phenolic acids from grape skin [142] and essential oils from coriander seeds [143]. For extraction of anthraquinones from Morinda citrifolia, the effectiveness of SCWE compared to that of other extraction methods, such as ethanol extraction in a stirred vessel, Soxhlet extraction and ultrasound-assisted extraction, has been studied [144]. The results indicated that SCWE extracts gave almost the same antioxidant activity as Soxhlet extracts, but SCWE extracts contained higher antioxidant activity than ethanol extracts and ultrasound-assisted extracts.

SCWE could be a good alternative industrial method to use for extraction of large amounts of phenolic compounds without toxic organic solvent residues. The products are ready to use as antioxidants for food products. Table 7 reports some recent work on the extraction of phenolics from plant materials using SCWE.

Table 7. Conditions for SCWE of phenolic compounds from plant-based materials.

\begin{tabular}{|c|c|c|c|c|c|c|}
\hline Sample & Analyte & $\begin{array}{c}\text { Temperature } \\
\left({ }^{\circ} \mathrm{C}\right)\end{array}$ & $\begin{array}{l}\text { Time } \\
(\mathrm{min})\end{array}$ & $\begin{array}{c}\text { Pressure } \\
\text { (bar) }\end{array}$ & $\begin{array}{c}\text { Solvent/sample } \\
(\mathrm{mL} / \mathrm{g})\end{array}$ & Ref. \\
\hline $\begin{array}{l}\text { Pomegranate } \\
\text { seeds }\end{array}$ & Phenolic compounds & $80-280$ & $15-120$ & 60 & $10-50$ & [145] \\
\hline Cinnamon bark & Phenolic compounds & 150,200 & 60 & 60 & -- & [146] \\
\hline Potato peel & Phenolic compounds & $100-240$ & $30-120$ & 60 & -- & [147] \\
\hline Rice bran & Phenolic compounds & $125-200$ & 5 & 20 & 2.5 & [148] \\
\hline $\begin{array}{l}\text { Terminalia } \\
\text { chebula }\end{array}$ & Phenolic compounds & $120-220$ & $10-150$ & 40 & -- & [149] \\
\hline Bitter melon & Phenolic compounds & $130-200$ & $10-120$ & -- & -- & {$[150]$} \\
\hline Oregano leaves & Phenolic compounds & $25-200$ & 15,30 & 103.4 & -- & [151] \\
\hline Green tea & $\begin{array}{l}\text { Catechin and } \\
\text { epicatechin }\end{array}$ & $140-260$ & -- & $38-72$ & 20 & {$[152]$} \\
\hline
\end{tabular}




\subsection{High Hydrostatic Pressure Extraction (HHPE)}

Another novel technique that can be utilized to extract phenolics from plants is HHPE. This method utilizes non-thermal super-high hydraulic pressure (1,000-8,000 bar) and works on the basis of mass transport phenomena $[153,154]$. The pressure applied increases plant cell permeability, leading to cell component diffusivity according to mass transfer and phase behavior theories $[153,155,156]$. A main disadvantage of methods such as HHPE, SCWE and SFE is that expensive equipment is required; i.e., a solvent transporting pump, a pressure vessel and system controller, and a collection device for the extract [157]. However, in the case of antioxidant extraction, in which products are in great demand and high purity of extract and processing efficiency are expected, the price of equipment might not play a critical role in selection of these methods [158].

HHPE involves creation of a huge pressure difference between the cell membrane interior and exterior and allows solvent to penetrate into the cell causing leakage of cell components $[153,155]$. HHPE can also cause cell deformation and protein denaturation, which can reduce cell selectivity and increase extraction yield [159].

HHPE is usually conducted at ambient temperature using different solvents from polar to non-polar, depending on the bioactive compounds to be extracted. The feasibility of HHPE to extract phenolic compounds from plant material is clearly demonstrated in some studies. Higher yields of phenolic compounds from Maclura pomifera fruits, anthocyanins from grape by-products and flavonoids from propolis have been obtained using HHPE compared with conventional extraction methods $[72,153,160]$. HHPE is also reported to be suitable to extract polyphenols from green tea leaves [159]. A higher yield of soluble polyphenols in the juice of cashew apples has been obtained using HHPE compared to other methods [161].

\subsection{Other Extraction Methods}

Pulsed electric field (PEF) processing is a non-thermal technique requiring low energy to increase cell membrane breakdown and mass transfer [162]. PEF can be operated continuously at room temperature and performed in a matter of seconds [163]. Such positive factors play an important role in minimizing quality deterioration of food compounds, especially bioactive materials [163]. Application of PEF to red cabbage, strawberry, must of tempranillo grapes, chardonnay grapes and merlot grapes increased the yield of total phenolics extracted [164-168]. In contrast, Turk et al. [169] reported a lower yield of phenolic compounds of apple juice extracted by PEF.

Accelerated solvent extraction (ASE) is an automated technique using common organic solvents to extract phenolics from plant materials [170]. ASE operates under nitrogen at high temperature and pressure, which helps the solvent penetrate rapidly into the plant cells and prevents degradation of phenolic compounds. Compared to conventional methods, the amount of solvent and extraction time are dramatically lower [171].

Sequential alkaline extraction is a method used to extract free and bound phenolic compounds from plant materials [105]. Free phenolics were extracted using water, pure organic or aqueous organic solvent under a nitrogen atmosphere in a water bath for $20 \mathrm{~min}$. The solid residue was then hydrolyzed 
with $\mathrm{NaOH}$ for $1 \mathrm{~h}$ under $\mathrm{N}_{2}$ in the dark at room temperature. The alkaline extract was treated by $\mathrm{HCl}$ to reach $\mathrm{pH} 2$, centrifuged, and the extract was used for the determination of bound phenolics.

Enzymatic treatment of plant samples is another technique suitable for the liberation of phenolic compounds. Phenolics in plant materials largely appear to be linked with plant cell wall polysaccharides by both hydrophilic and hydrophobic bonds [172]. The addition of enzymes might disintegrate the phenolic-cell wall matrix bonds and enhance phenolic extraction $[24,173,174]$. Recently, enzymatic hydrolysis using a combination of pectinase, cellulase and hemicellulase was shown to enhance phenolic extraction from raspberry solid waste [175]. Maier et al. [176] developed the application of enzymes to phenolic extraction from grape pomace. Kapasakalidis et al. [61] reported that commercial cellulose enzyme preparations promote the extraction of polyphenols and anthocyanins from black currant pomace. In other research, a comparison of the application of three different types of enzyme preparations including $\alpha$-amylase, Viscozyme L, and Ultraflo L was conducted on Ipomoea batatas (sweet potato) stem [177]. Ultraflo L and Viscozyme L facilitated phenolic recovery and resulted in a higher yield of ferulic acid and vanillic acid, respectively, in the extract. Hong and Van Veit [178] compared UAE techniques and enzyme-assisted extraction of phenolic compounds from acerola fruit, finding, in contrast, a higher yield of phenolics using novel UAE methods than enzymatic extraction.

In summary, MAE, UMAE, SFE and pressurized solvent extraction methods such as SCWE and HHPE are fast and efficient unconventional extraction methods developed for extracting analytes from plant matrices. They are emerging as good alternatives to conventional extraction methods, mainly due to lack of need for organic solvents and relatively low extraction times. Due to differing availabilities of instruments in analytical laboratories, sample complexity, solvent types, extraction time and temperature, sample-solvent ratio, type of target extract and many other factors, selection of extraction methods or even placing them in order of their advantages and disadvantages is difficult. For research-scale extraction, however, UMAE is highly recommended for many plant-based samples because of its effectiveness and relatively low cost.

\section{Quantification of Phenolics}

Despite a very large number of published investigations, quantification of various phenolic structural groups remains difficult $[120,179]$. Thus there is great scope for developing quantification methods based on the type of phenolic group. [180]. High performance liquid chromatography (HPLC) and gas chromatography (GC), or their combinations, with mass spectrometry are the two most commonly applied methods to quantify phenolic compounds. Other relevant techniques include spectrophotometric assays [28].

\subsection{Spectrophotometric Assays}

Spectrophotometry is one of the relatively simple techniques for quantification of plant phenolics. The Folin-Denis and Folin-Ciocalteu methods were the two widely used specrophotometric assays to measure total phenolics in plant materials for many years [181,182]. Both methods are based on a chemical reduction involving reagents containing tungsten and molybdenum [24]. The products of this reduction in the presence of phenolic compounds have a blue color with a broad light absorption 
spectrum around $760 \mathrm{~nm}$. The reagents for both methods do not react specifically with only phenols but also with other substances like ascorbic acid, aromatic amines and sugars [183].

Total phenolic quantification, total flavonoids, proanthocyanidin (condensed tannin) and hydrolysable tannin can also be estimated by colorimetric methods. Methanolic or ethanolic extracts of plant phenols mixed with $\mathrm{AlCl}_{3}$ allow measurement of total flavonoids in the range 410-423 nm [184,185].

Vanillin and dimethylaminocinnamaldehyde (DMCA) assays are used to determine the level of proanthocyanidins [28]. These methods can provide information about the degree of polymerization and the hydroxylation pattern and stereochemistry of flavan-3-ol subunits [186,187]. Catechin is usually used as a standard in the vanillin method and as a result may lead to the over-estimation of proanthocyanidins. The accuracy of the DMCA assay to quantify proanthocyanidins is also questionable [188].

The butanol-HCl and bovine serum albumin (BSA) methods are the other proanthocyanidin determination techniques. The butanol- $\mathrm{HCl}$ method is based on cleavage of interflavonoid bonds in proanthocyanidin using hot acid, followed by an auto-oxidation reaction to convert flavan-3-ols to anthocyanidin. The red extract formed has a maximum absorbance at around $550 \mathrm{~nm}$ [189]. In the BSA method, insoluble tannin-protein complexes are precipitated by treating samples with bovine serum albumin. The tannin-protein complex is dissolved in alkaline sodium dodecyl sulphate-triethanolamine solution and reacted with ferric chloride solution to form a violet complex with a maximum absorbance at $510 \mathrm{~nm}[190]$.

A validated method to quantify proanthocyanidin in grape extract based on precipitation of proanthocyanins using methyl cellulose has been published. The proanthocyanidins form an insoluble polymer after reacting with methyl cellulose [191]. In this method, proanthocyanidin concentration can be checked by measuring absorbance before and after methyl cellulose treatment [192]. Hydrolysable tannins can be evaluated using the potassium iodate method, rhodanine method and sodium nitrite method [1]. Among them, potassium iodate is the most popular method for screening samples. A red color with a maximum absorbance of 500-550 $\mathrm{nm}$ appears due to the reaction of methyl gallate and potassium iodate [187]. The rhodanine and sodium nitrite methods can also be used to determine hydrolysable tannins based on the presence of gallic and ellagic acid in the sample, respectively [193,194]. Another spectrophotometric method used to quantify flavonones and dihydroflavonols is based on their interaction with acidic 2,4-dinitrophenylhydrazine [195]. Pinocembrin is the standard used in this assay and the absorbance is measured at $486 \mathrm{~nm}$ [196].

Anthocyanins constitute the other main class of phenolic compounds measured by spectrophotometry. The main spectrophotometric assays applied to determine anthocyanins were reviewed by Giusti and Wrolstad [197]. Quantification of anthocyanin takes place in weak acidic media in the wavelength range 490-550 $\mathrm{nm}$ [198]. Colorimetric techniques to determine phenolics are simple and economical but only give an estimation of phenolic compound concentrations above a certain minimum level and do not quantify phenolics individually; however, these techniques can be useful for quick and relatively inexpensive screening of numerous samples [120]. 


\subsection{Gas Chromatography}

Gas chromatography (GC) is another technique applied for the separation, identification and quantification of phenolic compounds such as phenolic acids [199], condensed tannins [200] and flavonoids [201]. The major concerns of GC analysis, that are not applicable to HPLC techniques, are the derivatization and volatility of phenolic compounds. With GC, quantification of phenolics from food matrices may involve clean-up steps such as lipid removal from the extract, release of phenolics from the glycoside and ester bonds in enzymatic [202], alkaline [203] and acidic [204] media and chemical modification steps, such as transformation to more volatile derivatives [180].

There are a several types of reagents used to modify and create volatile derivatives. Ethyl and methyl chloroformate, diazomethane and dimethyl sulfoxide in combination with methyl iodate are used to make methyl or ethyl esters of phenolics. However, in some studies, substantial confusion may occur due to the presence of methyl esters in a natural form [205-207]. Another generation of reagents, which have advantages in the creation of volatile compounds, are the trimethylsylil family of compounds, such as trifluoroacetymide, $N$-(tert-butyldimethylsilyl)- $N$-methyltrifluoroacetamide and trimethylsilyl derivatives $[120,208]$. The silylation reaction is simple, free of unwanted side products and produces tremendously volatile products with no interference with the analysis [209]. Silyl derivatization is thus a very good option to identify phenolic compounds but more research is needed on identification of silyl derivatives [201].

Fused silica capillaries of $30 \mathrm{~m}$ lengths, with internal diameters of 25-32 $\mu \mathrm{m}$ and stationary phase particle size of $0.25 \mu \mathrm{m}$ are the most common columns used for phenolic quantification in GC techniques. There are exceptions, however, such as the column used by Shadkami et al. [200] with $15 \mathrm{~m}$ length and $10 \mu \mathrm{m}$ film thickness.

The use of a flame ionization detector (FID) is the most common method to detect phenolics but mass spectroscopy (MS) has become widespread recently [209]. GC provides more sensitivity and selectivity when combined with mass spectrometry [120]. For instance, the difficulties of flavonoid glycoside evaluation by conventional GC were solved when high-temperature-high-resolution GC-MS was applied [210]. Another study indicated that GC-MS analysis of phenolic and flavonoid standards was more efficient than that of HPLC, providing a fast analysis with better resolution and baseline separation of all standards with minimum co-elution [211]. Some of the gas chromatographic techniques for the analysis of phenolic compounds are presented in Table 8.

\subsection{High Performance Liquid Chromatography}

HPLC is the preferred technique for both separation and quantification of phenolic compounds [28]. Various factors affect HPLC analysis of phenolics, including sample purification, mobile phase, column types and detectors [24]. In general, purified phenolics are applied to an HPLC instrument utilizing a reversed phase C18 column (RP-C18), photo diode array detector (PDA) and polar acidified organic solvents [120]. Several reviews are available on the application of HPLC and the quantification of phenolics [24,209,212-214]. Normally, HPLC sensitivity and detection is based on purification of phenolics and pre-concentration from complex matrices of crude plant extracts. 
Table 8. Summary of GC conditions to detect molecules belonging to phenolic classes.

\begin{tabular}{|c|c|c|c|c|c|}
\hline Sample & Derivatization & Detected phenolics & Detection & Chromatographic assay details & Ref. \\
\hline Guarana & $\begin{array}{l}\text { Dried phenolic extract } \\
\text { derivatized with a mixture of } \\
\text { hexamethyldisiloxane and } \\
\text { dimethylchlorosilane in } \\
\text { pyridine }\end{array}$ & $\begin{array}{l}\text { 3-Hydroxybenzoic acid, benzoic acid, gallic } \\
\text { acid, syringic acid, isovanillic acid, } \\
\text { protocatechuic acid, catechin, caffeine, } \\
\text { epicatechin, quercetin }\end{array}$ & GC-MS & $\begin{array}{l}\text { Zebron ZB-5 ms fused silica capillary column } \\
(30 \mathrm{~m} \times 0.25 \mathrm{~mm} \text { I.D. } \times 0.25 \mu \mathrm{m} \text { film thickness); Oven } \\
\text { temperature: } 150{ }^{\circ} \mathrm{C} \text { held for } 5 \mathrm{~min} \text {, to } 295{ }^{\circ} \mathrm{C} \text { at } \\
3{ }^{\circ} \mathrm{C} / \mathrm{min} \text {, held for } 18 \mathrm{~min} \text {; Injector temperature: } 300^{\circ} \mathrm{C} \text {; } \\
\text { Carrier gas: helium flow at } 1 \mathrm{~mL} / \mathrm{min} \text {; Ion source } \\
\text { temperature: } 200{ }^{\circ} \mathrm{C} \text {; Transfer line temperature: } 290{ }^{\circ} \mathrm{C}\end{array}$ & {$[215]$} \\
\hline $\begin{array}{l}\text { Mirabell } \\
\text { e plums }\end{array}$ & $\begin{array}{l}\text { Dried phenolic extract } \\
\text { derivatized with } N, O \text { - } \\
\text { Bis(trimethylsilyl)trifluoro- } \\
\text { acetamide }\end{array}$ & $\begin{array}{l}\text { Benzoic acid, } p \text {-hydroxybenzaldehyde, } \\
\text { p-hydroxybenzoic acid, vanillin, 3,4- } \\
\text { dihydroxybenzoic acid, vanillic acid, gallic } \\
\text { acid, syringaldehyde, syringic acid, coniferyl } \\
\text { aldehyde, 3,5-dimethoxycinnamaldehyde, } \\
\text { dehydrodiconiferyl aldehyde, guajacyl- } \\
\text { glycerin-coniferyl aldehyde, guajacyl- } \\
\text { glycerin-coniferyl aldehyde }\end{array}$ & GC-MS & $\begin{array}{l}\text { HP } 5 \text { MS capillary column, }(30 \mathrm{~m} \times 0.25 \mathrm{~mm} \mathrm{I.D} \times 0.25 \mu \mathrm{m} \\
\text { film thickness). Oven temperature: } 100-270{ }^{\circ} \mathrm{C} \text { at } 4{ }^{\circ} \mathrm{C} / \mathrm{min} \text {, } \\
\text { held for } 20 \mathrm{~min} \text {; Injector temperature: } 250{ }^{\circ} \mathrm{C} \text {; Helium } \\
\text { flow at } 0.9 \mathrm{~mL} / \mathrm{s} \text {; Ion source temperature: } 230{ }^{\circ} \mathrm{C} \text {; Transfer } \\
\text { line temperature: } 280{ }^{\circ} \mathrm{C}\end{array}$ & {$[216]$} \\
\hline $\begin{array}{l}\text { Guava bagasse, } \\
\text { Cabernet } \\
\text { Sauvignon, Pinot } \\
\text { Noir, and Isabella } \\
\text { grape marcs } \\
\text { wastes }\end{array}$ & --------------------- & $\begin{array}{l}\text { Succinic acid, azelaic acid, syringic acid, } \\
\text { p-coumaric acid, gallic acid, ferulic acid, } \\
\text { caffeic acid, epicatechin, quercetin, } \\
\text { myricetin }\end{array}$ & GC-MS & $\begin{array}{l}\text { RTX 5MS capillary column }(30 \mathrm{~m} \times 0.25 \mathrm{~mm} \text { ID } \times 0.25 \mu \mathrm{m} \\
\text { film thickness }) \text {; Oven }\end{array}$ & [199] \\
\hline Cranberry & $\begin{array}{l}\text { Dried phenolic extract } \\
\text { derivatized with a mixture of } \\
\mathrm{N}, \mathrm{O} \text {-Bis(trimethylsilyl)- } \\
\text { trifluoroacetamide and } 1 \% \\
\text { trimethylchlorosilane in } \\
\text { pyridine }\end{array}$ & $\begin{array}{c}\text { Benzoic acid, } o \text {-hydroxybenzoic acid, trans- } \\
\text { cinnamic acid, } m \text {-hydroxybenzoic acid, } \\
p \text {-hydroxybenzoic acid, } p \text {-hydroxyphenyl } \\
\text { acetic acis }\end{array}$ & GC-MS & $\begin{array}{l}\text { Temperature: } 80^{\circ} \mathrm{C} \text { for } 1 \mathrm{~min} \text {, to } 250^{\circ} \mathrm{C} \text {, at } 20^{\circ} \mathrm{C} / \mathrm{min} \text {, held } \\
1 \mathrm{~min} \text {, to } 300^{\circ} \mathrm{C} \text { at } 6^{\circ} \mathrm{C} / \mathrm{min} \text {, held } 5 \mathrm{~min} \text {, to } 310^{\circ} \mathrm{C} \text { at } \\
15^{\circ} \mathrm{C} / \mathrm{min} \text { held } 10 \mathrm{~min} \text {, to } 320^{\circ} \mathrm{C} \text { at } 20^{\circ} \mathrm{C} / \mathrm{min} \text {, held } 10 \mathrm{~min} \text {; } \\
\text { Injector temperature: } 280{ }^{\circ} \mathrm{C} \text {; Transfer line temperature: } \\
280^{\circ} \mathrm{C} \text {. DB-5 fused-silica capillary column }(30 \mathrm{~m} \times 0.32 \mathrm{~mm} \\
\text { ID } \times 0.25 \mu \mathrm{m} \text { film thickness })\end{array}$ & {$[217]$} \\
\hline
\end{tabular}


Table 8. Cont.

\begin{tabular}{|c|c|c|c|c|c|}
\hline Sample & Derivatization & Detected phenolics & Detection & Chromatographic assay details & Ref. \\
\hline \multirow[t]{2}{*}{ Saffron corms } & \multirow[t]{2}{*}{$\begin{array}{l}\text { Dried phenolic extract } \\
\text { derivatized with a mixture of } \\
N \text {-methyl- } N \text {-(trimethylsilyl) } \\
\text { trifluoroacetamide and } \\
\text { iodotrimethylsilane }\end{array}$} & $\begin{array}{l}\text { Acetic acid, } o \text {-phthalic acid, 2,3-dihydroxy- } \\
\text { benzoic acid, vanillic acid, } o \text {-hydroxy- } \\
\text { cinnamic acid, 2,4-dihydroxy-benzoic acid, } \\
\text { p-coumaric acid, ferulic acid, caffeic acid, } \\
\text { sinapic acid, epicatechin, catechin. }\end{array}$ & \multirow[t]{2}{*}{ GC-MS } & $\begin{array}{l}\text { Oven temperature: } 80^{\circ} \mathrm{C} \text { for } 1 \mathrm{~min} \text {, to } 220^{\circ} \mathrm{C} \text {, at } \\
10{ }^{\circ} \mathrm{C} / \mathrm{min} \text {, to } 310^{\circ} \mathrm{C} \text {, at } 20^{\circ} \mathrm{C} / \mathrm{min} \text {, held } 6 \mathrm{~min} \text {; Injector } \\
\text { temperature: } 280{ }^{\circ} \mathrm{C} \text {; } \\
\text { Detector temperature: } 305^{\circ} \mathrm{C} \text {; Transfer line } \\
\text { temperature: } 280^{\circ} \mathrm{C} \text {. }\end{array}$ & \\
\hline & & $\begin{array}{l}\text { Quercetin, myricetin, } m \text {-methylbenzoic acid. } \\
\text { catechol, vanillin, salicylic acid, cinnamic } \\
\text { acid, } p \text {-hydroxybenzoic acid, syringic acid, } \\
p \text {-coumaric acid, gallic acid, } t \text {-ferulic acid, } \\
\text { caffeic acid, gentisic acid }\end{array}$ & & $\begin{array}{l}\text { DB-5 capillary column }(30 \mathrm{~m} \times 0.25 \mathrm{~mm} \text { ID } \times 0.25 \mu \mathrm{m} \\
\text { film thickness); Oven temperature: } 140{ }^{\circ} \mathrm{C} \text { for } 2 \mathrm{~min} \text {, to } \\
\qquad 270{ }^{\circ} \mathrm{C} \text { at } 5^{\circ} \mathrm{C} / \mathrm{min}\end{array}$ & [218] \\
\hline \multirow[t]{2}{*}{ Mangosteen fruit } & $\begin{array}{c}\text { Dried phenolic extract } \\
\text { derivatized with } N, O- \\
\text { bis(trimethylsilyl)acetamide }\end{array}$ & $\begin{array}{l}\text { Hydroxybenzoic acid, protocatechuic acid, } \\
\text { vanillic acid, caffeic acid, } p \text {-coumaric acid, } \\
\text { ferulic acid, } p \text {-hydroxyphenylacetic acid, } \\
\text { 3,4-dihydroxymandelic, cinnamic acid }\end{array}$ & \multirow[t]{2}{*}{ GC-MS } & \multirow{2}{*}{$\begin{array}{l}\text { Held } 20 \mathrm{~min} \text {; Injector temperature: } 270{ }^{\circ} \mathrm{C} \text {; Transfer line } \\
\text { temperature: } 270{ }^{\circ} \mathrm{C} \text {. SPB- } 1 \text { silica-fused capillary column } \\
(30 \mathrm{~m} \times 0.25 \mathrm{~mm} \text { ID } \times 0.25 \mu \mathrm{m} \text { film thickness }) \text {; Oven } \\
\text { temperature: } 120^{\circ} \mathrm{C} \text { held } 2 \mathrm{~min} \text {, to } 260^{\circ} \mathrm{C} \text { at } 20^{\circ} \mathrm{C} / \mathrm{min} \text {, } \\
\text { held } 10 \mathrm{~min} \text {; Injector temperature: } 240^{\circ} \mathrm{C} \text {; Helium flow at } \\
\quad 28 \mathrm{~cm}^{3} / \mathrm{min} \text {; Transfer line temperature: } 240^{\circ} \mathrm{C} \text {. }\end{array}$} & [208] \\
\hline & & & & & \\
\hline Green tea & $\begin{array}{l}\text { Dried phenolic extract } \\
\text { derivatized with trimethyl- } \\
\text { sulfonium hydroxide and } \\
\text { trimethylsilyl diazomethane }\end{array}$ & $\begin{array}{l}\text { Catechin, epicatechin, epigallocatechin, } \\
\text { gallocatechin, kaempferol, quercetin }\end{array}$ & GC-MS & $\begin{array}{l}\text { A ZB-5HT Inferno capillary column }(15 \mathrm{~m} \times 0.32 \mathrm{~mm} \text { ID } \\
\times 0.10 \mu \mathrm{m} \text { film thickness }) \text { O Oven temperature: } 100^{\circ} \mathrm{C} \text { held } \\
\text { for } 5 \mathrm{~min} \text {, to } 375^{\circ} \mathrm{C} \text { at } 20^{\circ} \mathrm{C} / \mathrm{min} \text {, held for } 5 \mathrm{~min} \text {; Injector } \\
\text { temperature: } 350^{\circ} \mathrm{C} \text {; Transfer line temperature: } 300^{\circ} \mathrm{C}\end{array}$ & [200] \\
\hline $\begin{array}{l}\text { Various plant } \\
\text { extracts }\end{array}$ & $\begin{array}{c}\text { Dried phenolic extract } \\
\text { derivatized with a mixture of } \\
\text { trimethylchlorosilane and } \\
\mathrm{N}, \mathrm{O} \text {-bis(trimethylsilyl)- } \\
\text { trifluoroacetamide with } \\
\text { dimethyldichlorosilane in } \\
\text { toluene and } \\
\text { dimethyldichlorosilane }\end{array}$ & $\begin{array}{l}\text { Gallic acid, } p \text {-hydroxybenzoic } \\
\text { acid, gentisic acid, } \\
\text { p-coumaric acid, vanillic } \\
\text { acid, ferulic acid, syringic } \\
\text { acid, catechin }\end{array}$ & GC-MS & $\begin{array}{l}\text { CP-Sil } 8 \text { capillary column }(30 \mathrm{~m} \times 0.32 \mathrm{~mm} \text { ID } \times 0.25 \mu \mathrm{m} \\
\text { film thickness })\end{array}$ & [195] \\
\hline
\end{tabular}


Table 8. Cont.

\begin{tabular}{|c|c|c|c|c|c|}
\hline Sample & Derivatization & Detected phenolic & Detection & Chromatographic assay details & Ref. \\
\hline Propolis & $\begin{array}{c}\text { Dried phenolic extract } \\
\text { derivatized with } N, O- \\
\text { Bis(trimethylsilyl)trifluoro- } \\
\text { acetamide }\end{array}$ & $\begin{array}{l}\text { quercetin, apigenin, naringenin, } \\
\text { luteolin, caffeic acid, epicatechin, rutin, } \\
\text { hydroxytyrosol. } \\
\text { Ethyl hydrocinnamate, hydrocinnamic acid, } \\
\text { inositol, cinnamic acid, ferulic acid, caffeic } \\
\text { acid, pinostrobin }\end{array}$ & GC-MS & $\begin{array}{l}\text { Oven temperature: } 70{ }^{\circ} \mathrm{C} \text {, to } 135^{\circ} \mathrm{C} \text { at } 2{ }^{\circ} \mathrm{C} / \mathrm{min} \text {, held for } \\
10 \mathrm{~min} \text {, to } 220^{\circ} \mathrm{C} \text { at } 4{ }^{\circ} \mathrm{C} / \mathrm{min} \text {, held for } 10 \mathrm{~min} \text {, to } 270{ }^{\circ} \mathrm{C} \\
\text { at } 3.5^{\circ} \mathrm{C} / \mathrm{min} \text {, held for } 20 \mathrm{~min} \text {; Injector temperature: } \\
280{ }^{\circ} \mathrm{C} \text {; Transfer line temperature: } 290^{\circ} \mathrm{C} \text {. } \\
\text { Borosilicate capillary column } \\
(20 \mathrm{~mm} \times 0.3 \mathrm{~mm} \text { ID } \times 0.1 \mu \mathrm{m})\end{array}$ & [219] \\
\hline
\end{tabular}

Table 9. Summary of recent HPLC conditions for plant and food phenolic classes.

\begin{tabular}{|c|c|c|c|c|c|}
\hline Sample & Phenolic class & Column/Detector & Solvent/ Flow rate/ injection volume & $\begin{array}{l}\text { Temperature } \\
\left({ }^{\circ} \mathrm{C}\right) / \text { Detection } \\
\text { time (min) }\end{array}$ & Ref. \\
\hline $\begin{array}{l}\text { Mangosteen } \\
\text { pericarp }\end{array}$ & $\begin{array}{c}\text { Gallic acid, gentisic acid, protocatechuic acid, } \\
\text { gentisic acid, 4-hydroxybenzoic acid, veratric acid, } \\
\text { vanillic acid, caffeic acid, syringic acid, } p \text {-coumaric } \\
\text { acid, sinapic acid, ferulic acid, } t \text {-cinnamic acid } \\
\text { catechin, epicatechin }\end{array}$ & $\begin{array}{l}\text { Bondapak C18 column } \\
(300 \mathrm{~mm} \times 3.9 \mathrm{~mm} \text { ID } \times \\
5 \mu \mathrm{m}) / \text { PDA }^{\mathrm{b}}, \mathrm{ESI}^{-M S}{ }^{\mathrm{e}}\end{array}$ & $\begin{array}{c}\text { Water : methanol : } \\
\text { acetic acid (85:14:1); Flow rate: } 1.0 \mathrm{~mL} / \mathrm{min} \text {; } \\
\text { Injection volume: } 20 \mu \mathrm{L}\end{array}$ & Ambient/ 45 & [220] \\
\hline Mulberry fruit & $\begin{array}{c}\text { Cyanidin 3-O-rutinoside, cyanidin 3-O-glucoside, } \\
\text { pelargonidin 3-O-glucoside, pelargonidin 3-O- } \\
\text { rutinoside }\end{array}$ & $\begin{array}{c}\text { RP C18 column }(250 \\
\mathrm{mm} \times 4.6 \mathrm{~mm} \mathrm{ID}, 5 \mu \mathrm{m}) / \\
\text { PDA }^{\mathrm{b}}, \mathrm{ESI}^{-M S}{ }^{\mathrm{e}}\end{array}$ & $\begin{array}{l}\text { A: water containing } 0.1 \% \text { TFA (trifluoroacetic } \\
\text { acid); B: acetonitrile containing } 0.1 \% \text { TFA; Elution } \\
\text { profile: } 0-2 \text { min, } 10 \% \mathrm{~B} ; 2-35 \mathrm{~min}, 10-90 \% \mathrm{~B} \text {; } \\
35-40 \mathrm{~min}, 90-100 \% \mathrm{~B} ; 40-60 \mathrm{~min}, 100 \% \mathrm{~B} / \text { Flow } \\
\text { rate: } 1.0 \mathrm{~mL} / \mathrm{min} \text {; } \mathrm{NM}^{\mathrm{a}}\end{array}$ & Ambient/ 60 & [221] \\
\hline Fruit juice & $\begin{array}{l}\text { Cyanidin, peonidin, delphinidin, petunidin, malvidin, } \\
\text { pelargonidin }\end{array}$ & $\begin{array}{l}\text { ODS-3 column }(250 \mathrm{~mm} \\
\times 4.6 \mathrm{~mm} \mathrm{ID} \times 5 \mu \mathrm{m}) /^{\text {PDA }^{\mathrm{b}}}\end{array}$ & $\begin{array}{l}\text { A: acetonitrile; B: water containing } 10 \% \text { acetic acid } \\
\text { and } 1 \% \text { phosphoric acid; Elution profile: } 25 \mathrm{~min} \text {, } \\
2-20 \% \mathrm{~A} ; 5 \mathrm{~min}, 20-40 \% \text {; Flow rate: } 1.0 \mathrm{~mL} / \mathrm{min} \text {; } \\
\text { Injection volume: } 25 \mu \mathrm{L}\end{array}$ & $\mathrm{NM}^{\mathrm{a}} / 50$ & [222] \\
\hline
\end{tabular}


Table 9. Cont

\begin{tabular}{|c|c|c|c|c|c|}
\hline Sample & Phenolic class & Column/Detector & Solvent/ Flow rate/ injection volume & $\begin{array}{l}\text { Temperature } \\
\left({ }^{\circ} \mathrm{C}\right) / \text { Detectio } \\
\text { n time (min) }\end{array}$ & Ref. \\
\hline $\begin{array}{l}\text { Maytenus } \\
\text { aquifolium and } \\
\text { Maytenus } \\
\text { ilicifolia } \text { Leaves }\end{array}$ & Quercetin, kaempferol derivatives, rutin & $\begin{array}{l}\text { Supelcosil C8 and C18 } \\
(250 \mathrm{~mm} \times 4.6 \mathrm{~mm} \mathrm{ID} \times \\
5 \mu \mathrm{m}) \text { column } / \mathrm{PDA}^{\mathrm{b}}\end{array}$ & $\begin{array}{c}\text { A: water containing } 2.0,2.5 \text { or } 3.0 \% \text { formic acid or } \\
0.3 \% \text { trifluoroacetic acid; B: acetonitrile or } \\
\text { methanol; Various elution profiles; Flow rate } \\
1.0 \mathrm{~mL} / \mathrm{min} / \text { Injection volume: } 10 \mu \mathrm{L}\end{array}$ & $\begin{array}{l}\text { 35/ Different } \\
\text { detection } \\
\text { times }\end{array}$ & {$[223]$} \\
\hline Apple & $\begin{array}{c}\text { Gallic acid, chlorogenic acid, } \\
\text { catechin, epicatechin, procyanidin, phloridzin, } \\
\text { cyanidin 3-galactoside, } \\
\text { quercetin 3-rutinoside, quercetin } \\
\text { 3-galactoside, quercetin 3-glucoside, } \\
\text { quercetin 3-rhamnoside }\end{array}$ & $\begin{array}{c}\mathrm{RP} \mathrm{C} 18(250 \mathrm{~mm} \times 4.6 \\
\mathrm{mm} \mathrm{ID} \times 4 \mu \mathrm{m}) \text { column} / \\
\text { PDA }^{\mathrm{b}}\end{array}$ & $\begin{array}{l}\text { A: water containing } 1 \% \text { TFA, B: ACN containing } \\
\text { 1\% TFA; Elution profile: } 0-10 \mathrm{~min}, 10 \% \mathrm{~B} ; 10-45 \\
\text { min, } 10-20 \% \mathrm{~B} ; 45-50 \mathrm{~min}, 20-50 \% \mathrm{~B} ; 50-55 \\
\text { min, isocratic } 50 \% \text {; } 55-60 \mathrm{~min}, 50-10 \% \mathrm{~B} \text {. Flow } \\
\text { rate: } 1 \mathrm{~mL} / \mathrm{min} \text {. Injection volume: } 10 \mu \mathrm{L}\end{array}$ & $40 / 60$ & {$[224]$} \\
\hline Medicinal plants & $\begin{array}{c}\text { Cyanidin glucoside, pelargonidin glucoside, } \\
\text { gallocatechin-catechin gallate, afzelechin - catechin } \\
\text { dimer, gallocatechin catechin gallate, ferulic acid } \\
\text { glucoside, rutin, naringenin-7-O-rutinoside }\end{array}$ & $\begin{array}{l}\mathrm{RP} \text { C18 }(250 \mathrm{~mm} \times 4.6 \\
\mathrm{mm} \mathrm{ID} \times 5 \mu \mathrm{m}) \text { column } / \\
\text { PDA }^{\mathrm{b}}, \mathrm{ESI}^{-\mathrm{MS}^{\mathrm{e}}}\end{array}$ & $\begin{array}{l}\text { A: water containing 1\% formic acid, B: acetonitrile; } \\
\text { Elution profile: } 30 \mathrm{~min}, 90-75 \% \mathrm{~A} ; 30-45 \mathrm{~min} \text {, } \\
\begin{array}{r}\text { 75-40\% A; Flow rate: } 1 \mathrm{~mL} / \mathrm{min} \text {; Injection volume: } \\
20 \mu \mathrm{L}\end{array}\end{array}$ & $25 / 45$ & {$[225]$} \\
\hline Food samples & $\begin{array}{l}\text { Monomeric, dimeric and trimeric procyanidins, } \\
\text { catechin, epicatechin }\end{array}$ & $\begin{array}{l}\text { RP } 18(250 \mathrm{~mm} \times 2 \mathrm{~mm} \\
\text { ID } \times 5 \mu \mathrm{m}) \text { column } / \\
\text { PDA }^{\mathrm{b}}, \mathrm{FLD}^{\mathrm{d}}, \mathrm{ESI}- \\
\mathrm{MS} / \mathrm{MS}\end{array}$ & $\begin{array}{l}\text { A: water containing } 0.1 \% \text { formic acid; } \mathrm{B} \text { : } \\
\text { acetonitrile containing } 0.1 \% \text { formic acid; Elution } \\
\text { profile: } 0-10 \mathrm{~min}, 10 \% \mathrm{~B} ; 10-30 \mathrm{~min}, 15 \% \mathrm{~B} \text {; } \\
30-65 \mathrm{~min}, 40 \% \mathrm{~B} \text {. Flow rate: } 300 \mu \mathrm{L} / \mathrm{min} \text {; } \\
\text { Injection volume: } 20 \mu \mathrm{L}\end{array}$ & $25 / 30$ & {$[226]$} \\
\hline Oregano & $\begin{array}{l}\text { Quercetin, fisetin, kaempferol, luteolin, apigenin, } \\
\text { eriodictyol, hesperetin, taxifolin, }(+) \text {-catechin, } \\
(-) \text {-epicatechin }\end{array}$ & $\begin{array}{c}\text { Hypersil C18 ODS } \\
(250 \mathrm{~mm} \times 4.6 \mathrm{~mm} \mathrm{ID} \times \\
5 \mu \mathrm{m}) \text { column } / \text { PDA }^{\mathrm{b}} \\
\text { ESI-MS-MS }\end{array}$ & $\begin{array}{c}\text { A: water; B: methanol; C: acetonitrile, each } \\
\text { containing } 0.2 \% \text { trifluroacetic acid; Elution profile: } \\
\text { Initial, } 90 \% \mathrm{~A}, 6 \% \mathrm{~B}, 4 \% \mathrm{C} ; 5 \mathrm{~min}, 85 \% \mathrm{~A}, 9 \% \mathrm{~B} \text {, } \\
6 \% \mathrm{C} ; 5-35 \mathrm{~min}, 71 \% \mathrm{~A}, 17.4 \% \mathrm{~B}, 11.6 \% \mathrm{C} ; \\
35-95 \mathrm{~min}, 0 \% \mathrm{~A}, 85 \% \mathrm{~B}, 15 \% \mathrm{C} \text {; Flow rate: } \\
\qquad 1 \mathrm{~mL} / \mathrm{min} \text {; } \mathrm{NM}^{\mathrm{a}}\end{array}$ & $30 / \mathrm{NM}^{\mathrm{a}}$ & {$[51]$} \\
\hline
\end{tabular}


Table 9. Cont

\begin{tabular}{|c|c|c|c|c|c|}
\hline Sample & Phenolic class & Column/Detector & Solvent/ Flow rate/ injection volume & $\begin{array}{l}\text { Temperature } \\
\left({ }^{\circ} \mathrm{C}\right) / \text { Detection } \\
\text { time }(\mathbf{m i n})\end{array}$ & Ref. \\
\hline Lotus leaves & $\begin{array}{l}\text { Myricetin 3-O-glucoside, quercetin 3-O- } \\
\text { arabinopyranosyl, quercetin 3-O-glucuronide, } \\
\text { kaempferol 3-O-galactoside, astragalin, isorhamnetin } \\
\text { 3-O-glucoside, kaempferol 3- } O \text {-glucuronide, } \\
\text { quercetin }\end{array}$ & $\begin{array}{l}\text { C18 }(150 \mathrm{~mm} \times 4.6 \mathrm{~mm} \\
\mathrm{ID} \times 3.5 \mu \mathrm{m}) \text { column/ } \\
\text { PDA }^{\mathrm{b}}, \mathrm{ESI}-\mathrm{MS}^{\mathrm{e}}\end{array}$ & $\begin{array}{l}\text { A: water containing } 0.5 \% \text { formic acid; B: acetonitrile } \\
\text { containing } 0.1 \% \text { formic acid; Elution profile: } 0-10 \\
\text { min, } 12 \% \mathrm{~B} ; 10-32 \mathrm{~min}, 12-20 \% \mathrm{~B} ; 32-40 \mathrm{~min}, 20- \\
30 \% \mathrm{~B} ; 40-48 \mathrm{~min}, 30-60 \% \mathrm{~B} ; 48-49 \mathrm{~min}, 60-12 \% \mathrm{~B} \text {; } \\
\quad 49-53 \mathrm{~min} 12 \% \mathrm{~B} \text {; Flow rate: } 0.6 \mathrm{~mL} / \mathrm{min} \text {; } \mathrm{NM}^{\mathrm{a}}\end{array}$ & $30 / 53$ & [227] \\
\hline $\begin{array}{l}\text { Bilberries } \\
\text { and } \\
\text { Blueberries }\end{array}$ & $\begin{array}{l}\text { Delphinidin-3- } O \text {-glucopyranoside, delphinidin-3- } O \text { - } \\
\text { galactopyranoside, cyanidin-3- } O \text {-arabinopyranoside, } \\
\text { malvidin-3- } O \text {-arabinopyranoside, petunidin-3-O- } \\
\text { galactopyranoside }\end{array}$ & $\begin{array}{c}\mathrm{C} 18(250 \mathrm{~mm} \times 4.6 \mathrm{~mm} \\
\mathrm{ID} \times 3 \mu \mathrm{m}) \text { column} / \\
\mathrm{UV}-\mathrm{VISc}\end{array}$ & $\begin{array}{l}\text { A: acetonitrile: water: formic acid }(87 / 3 / 10) \text {; B } \\
\text { acetonitrile: water: formic acid (50/40/10); Elution } \\
\text { profile: } 0-20 \mathrm{~min}, 2 \%-14 \% \mathrm{~B} ; 20-40 \mathrm{~min}, 14 \% \mathrm{~B} \text {; } \\
40-50 \mathrm{~min}, 15 \% \mathrm{~B} \text {; } 50-55 \mathrm{~min}, 19 \% \mathrm{~B} \text {; } 55-65 \mathrm{~min} \text {, } \\
20 \% \mathrm{~B} / \text { Flow rate: } 0.5 \mathrm{~mL} / \mathrm{min} \text {; Injection volume: } 20 \mu \mathrm{L}\end{array}$ & Ambient/ 65 & [228] \\
\hline $\begin{array}{l}\text { Persian } \\
\text { walnut }\end{array}$ & $\begin{array}{l}\text { 3-caffeoylquinic, 3-p-coumaroylquinic, 4- } p \text { - } \\
\text { coumaroylquinic acid, quercetin 3-galactoside, } \\
\text { quercetin 3-arabinoside, quercetin 3-xyloside, } \\
\text { quercetin 3-rhamnoside, quercetin 3-pentoside, } \\
\text { kaempferol 3-pentoside }\end{array}$ & $\begin{array}{l}\text { LiChroCART RP C } 18 \\
(250 \mathrm{~mm} \times 4 \mathrm{~mm} \text { ID } \times \\
5 \mu \mathrm{m}) / \text { PDA }^{\mathrm{b}}, \mathrm{MS}-\mathrm{MS}\end{array}$ & $\begin{array}{l}\text { A: water containing } 0.1 \% \text { TFA; B: methanol; Elution } \\
\text { profile: } 30 \mathrm{~min}, 30-50 \% \mathrm{~B} \text {; 30-32 min, } 70 \% \mathrm{~B} \text {; } \\
32-33 \mathrm{~min}, 80 \% \mathrm{~B}, 33-35 \mathrm{~min}, 80 \% \mathrm{~B} \text {; Flow rate: } \\
1 \mathrm{~mL} / \mathrm{min} \text {; Injection volume: } 5 \mu \mathrm{L}\end{array}$ & $\mathrm{NM}^{\mathrm{a}} / 35$ & [229] \\
\hline Rye grain & $\begin{array}{l}\text { Sinapic acid, syringic acid, vanillic acid, ferulic acid, } \\
\text { caffeic acid, } p \text {-hydroxybenzoic acid, protocatechuic } \\
\text { acid, } p \text {-coumaric acid, ferulic acid dehydrodimers }\end{array}$ & $\begin{array}{l}\text { Inertsil ODS-3 } \\
(150 \mathrm{~mm} \times 4.0 \mathrm{~mm} \\
\mathrm{ID} \times 3 \mu \mathrm{m} / \mathrm{PDA}^{\mathrm{b}}\end{array}$ & $\begin{array}{l}\text { A: } 50 \mathrm{mM} \mathrm{H}_{3} \mathrm{PO}_{4}(\mathrm{pH} 2.5) \mathrm{B} \text { : acetonitrile; Elution } \\
\text { profile: } 0-5 \mathrm{~min}, 95 \% \mathrm{~A} ; 5-17 \mathrm{~min}, 95-85 \% \mathrm{~A} ; 17-40 \\
\text { min, } 85-80 \% \mathrm{~A} ; 40-60 \mathrm{~min}, 80-50 \% \mathrm{~A} ; 60-65 \mathrm{~min} \\
50 \% \text { A. Flow rate: } 0.7 \mathrm{~mL} / \mathrm{min} \text {; Injection volume: } 10 \mu \mathrm{L}\end{array}$ & $35 / 67$ & [230] \\
\hline $\begin{array}{c}\text { Pomegranate } \\
\text { juices }\end{array}$ & $\begin{array}{l}\text { Delphinidin 3,5-diglucoside, cyanidin } \\
\text { 3,5-diglucoside, delphinidin 3-glucoside, } \\
\text { pelargonidin 3,5-diglucoside, ellagic acid }\end{array}$ & $\begin{array}{l}\text { RP C18 Nucleosil } \\
(125 \mathrm{~mm} \times 5.0 \mathrm{~mm} \\
\text { ID } \times 5.0 \mu \mathrm{m}) \text { column/ } \\
\text { UV-VIS }^{\mathrm{c}}\end{array}$ & $\begin{array}{c}\text { A: water containing } 2.5 \% \text { acetic acid; B: methanol } \\
\text { containing } 2.5 \% \text {, acetic acid; Elution profile: } 0-5 \mathrm{~min} \text {, } \\
100 \% \mathrm{~A} \text {; } 5-15 \mathrm{~min}, 90 \% \text {; } 15-45 \mathrm{~min}, 50 \% \mathrm{~A} ; \\
45-55 \mathrm{~min}, 100 \% \text { A. Flow rate: } 1.0 \mathrm{~mL} / \mathrm{min} \text {; Injection } \\
\text { volume: } 50 \mu \mathrm{L}\end{array}$ & $\mathrm{NM}^{\mathrm{a}} / 55$ & [231] \\
\hline
\end{tabular}


Table 9. Cont

\begin{tabular}{|c|c|c|c|c|c|c|}
\hline Sample & Phenolic class & Column/Detector & Solvent/ Flow rate/ injection volume & \multicolumn{2}{|c|}{$\begin{array}{l}\text { Temperature } \\
\left({ }^{\circ} \mathrm{C}\right) / \text { Detection } \\
\text { time (min) }\end{array}$} & Ref. \\
\hline Orange juice & $\begin{array}{c}\text { Gallic acid, protocatechuic acid, } p \text {-hydroxybenzoic acid, } \\
\text { vanillic acid, caffeic acid, chlorogenic acid, } \\
\text { p-coumaric acid, ferulic acid, sinapic acid, narirutin, } \\
\text { naringin, hesperidin, neohesperidin, didymin }\end{array}$ & $\begin{array}{c}\text { Ultrasphere ODS } \\
(250 \mathrm{~mm} \times 4.6 \mathrm{~mm} \\
\text { ID } \times 5 \mu \mathrm{m}) \text { column/ } \\
\text { UV-VIS }^{\mathrm{c}}\end{array}$ & $\begin{array}{l}\text { A: water containing 5\% formic acid; B: } \\
\text { acetonitrile/solvent A (60:40; v/v); Elution profile: } \\
0-10 \mathrm{~min}, 0 \% \mathrm{~B} \text {; } 10-40 \mathrm{~min}, 0-5 \% \mathrm{~B} ; 40-58 \mathrm{~min} \text {, } \\
5-15 \% \mathrm{~B} \text {; } 48-62 \mathrm{~min}, 15-25 \%, 62-93 \mathrm{~min}, 25-50 \% \mathrm{~B} \text {; } \\
93-96 \mathrm{~min}, 50-100 \% \mathrm{~B} \text {; Flow rate: } 1.0 \mathrm{~mL} / \mathrm{min} ; \mathrm{NM}^{\mathrm{a}}\end{array}$ & \multicolumn{2}{|c|}{$25 / 96$} & {$[232]$} \\
\hline Quinoa & $\begin{array}{l}\text { Apigenin-7-methyl ether, 1-O-galloyl- } \beta \text {-D-glucose, } \\
\text { protocatechuic acid 4- } O \text {-glucoside, vanillic glucoside, } \\
\text { penstebioside, ferulic acid 4- } O \text {-glucoside, ethyl-m- } \\
\text { digallate, gallocatechin, quercetin, kaempferol, rutin }\end{array}$ & $\begin{array}{c}\text { Kinetex C18 (100 } \\
\mathrm{mm} \times 4.6 \mathrm{~mm} \mathrm{ID} \times \\
2.6 \mu \mathrm{m}) \text { column/ PDA } \\
\mathrm{b}, \mathrm{ESI}^{\mathrm{M}} \mathrm{MS}^{\mathrm{e}}\end{array}$ & $\begin{array}{l}\text { A: water containing 1\% acetic acid; B: acetonitrile/ } \\
\text { solvent A (40:60; v/v); Elution profile: 0-3.5 min, 2\% } \\
\text { B; 3.5-4.5 min, 2-6\%; 4.5-6 min, 6-10\% B; 6-7.5 min, } \\
\text { 10-17\%; 7.5-13 min, } 17-36 \% \mathrm{~B} \text {; } 13-14 \mathrm{~min}, 36-38.5 \% \\
\text { B; } 14-19 \mathrm{~min}, 38.5-60 \% \mathrm{~B} \text {; } 19-24 \mathrm{~min}, 60-100 \% \mathrm{~B} \text {; } \\
24-30 \mathrm{~min}, 100 \% \mathrm{~B} \text {; } 30-32 \mathrm{~min}, 100-2 \% \mathrm{~B} \text {; Flow rate: } \\
0.8 \mathrm{~mL} / \mathrm{min} \text {; Injection volume: } 10 \mu \mathrm{L}\end{array}$ & \multicolumn{2}{|c|}{$25 / 30$} & {$[233]$} \\
\hline Pine needle & Catechin, proanthocyanidins & $\begin{array}{l}\text { SupelcoSil LC18 } \\
(250 \mathrm{~mm} \times 4.6 \mathrm{~mm} \\
\mathrm{ID} \times 5 \mu \mathrm{m}) \text { column/ } \\
\mathrm{UV}^{\mathrm{c}}\end{array}$ & \multicolumn{2}{|c|}{$\begin{array}{l}\text { A: acetonitrile; B: water containing } 0.3 \% \text { phosphoric acid; } \\
\text { Elution profile: } 0-35 \mathrm{~min}, 10-20 \% \mathrm{~A} ; 35-55 \mathrm{~min}, 20-90 \% \mathrm{~A} \text {; } \\
\text { Flow rate: } 0.7 \mathrm{ml} / \mathrm{min} \text {; Injection volume: } 10 \mu \mathrm{L}\end{array}$} & $\mathrm{NM}^{\mathrm{a}} / 47$ & {$[234]$} \\
\hline Apricot fruit & $\begin{array}{l}p \text {-aminobenzoic acid, chlorgenic acid, caffeic acid, } \\
\text { protocatechuic acid, ferulic acid, rutin, resveratrol, } \\
\text { quercetin }\end{array}$ & $\begin{array}{c}\text { Gemini C18 }(150 \mathrm{~mm} \\
\times 4.6 \mathrm{~mm} \mathrm{ID} \times 3 \mu \mathrm{m}) \\
\text { column} / \mathrm{UV}-\mathrm{VIS}^{\mathrm{c}}\end{array}$ & \multicolumn{2}{|c|}{$\begin{array}{l}\text { A: citric acid }(75 \mathrm{mM}) \text {; B: ammonium acetate }(25 \mathrm{mM}) \\
\text { Elution profile: } 0-1 \mathrm{~min}, 5 \% \mathrm{~B} ; 1-4 \mathrm{~min}, 5-6 \% \mathrm{~B} ; 4-20 \mathrm{~min} \text {, } \\
6-25 \% \mathrm{~B} ; 20-30 \mathrm{~min}, 25-100 \% \mathrm{~B} ; 30-36 \mathrm{~min}, 100 \% \mathrm{~B} \text {; } \\
36-38 \mathrm{~min}, 100-5 \% \mathrm{~B} ; 38-45 \mathrm{~min}, 5 \% \mathrm{~B} \text {; Flow rate: } \\
1.0 \mathrm{~mL} / \mathrm{min} \text {; Injection volume: } 20 \mu \mathrm{L}\end{array}$} & $35 / 45$ & {$[235]$} \\
\hline
\end{tabular}


Table 9. Cont

\begin{tabular}{|c|c|c|c|c|c|}
\hline Sample & Phenolic class & Column/Detector & Solvent/ Flow rate/ injection volume & $\begin{array}{c}\text { Temperature } \\
\left({ }^{\circ} \mathrm{C}\right) / \text { Detectio } \\
\text { n time (min) }\end{array}$ & Ref. \\
\hline Sage tea & $\begin{array}{l}\text { Carnosic acid, epirosmanol, luteolin-rutinoside, } \\
\text { salvianolic acid, apigenin-glucuronide, rosmarinic acid, } \\
\text { apigenin-rutinoside, luteolin-rutinoside, luteolin-7-O- } \\
\text { glucoside, monohydroxy benzoic acid, luteolin- } \\
\text { diglucuronide, caffeic acid, caffeoyl-fructosyl-glucose, } \\
\text { coumaroyl-hexose, protocatechuic acid }\end{array}$ & 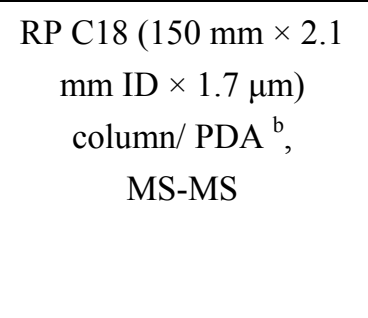 & $\begin{array}{l}\text { A: water containing } 0.1 \% \text { formic acid; B: } \\
\text { acetonitrile containing } 0.1 \% \text { formic acid; Elution } \\
\text { profile: } 0-14 \mathrm{~min}, 4-27 \% \mathrm{~A} ; 14-28 \mathrm{~min}, 27-59.7 \% \\
\text { A; } 28-28.2 \mathrm{~min}, 59.7-100 \% \mathrm{~A} ; 28.2-30.5 \mathrm{~min} \\
100 \% \mathrm{~A} ; 30.5-31 \mathrm{~min}, 100-4 \% \mathrm{~A} ; 31-34 \mathrm{~min}, 4 \% \\
\text { A; Flow rate: } 0.4 \mathrm{~mL} / \mathrm{min} \text {; Injection volume: } 3 \mu \mathrm{L}\end{array}$ & $40 / 28$ & [236] \\
\hline Almond skin & $\begin{array}{l}\text { Quercetin-3-O-glucoside, isorhamnetin-3-rutinoside, } \\
\text { kampferol-3-rutinoside, naringenin-7-O-glucoside, } \\
\text { isorhamnetin-3-glucoside, } p \text {-hydroxybenzoic acid, } \\
\text { naringenin, protocatechuic acid, vanillic acid }\end{array}$ & $\begin{array}{c}\mathrm{RP} \text { C18 }(50 \mathrm{~mm} \times 2 \mathrm{~mm} \\
\mathrm{ID}, \times 2.5 \mu \mathrm{m}) \text { column} / \\
\mathrm{ESI}^{\mathrm{M} M S}{ }^{\mathrm{e}}\end{array}$ & $\begin{array}{l}\text { A: water containing } 0.1 \% \text { formic acid. B: } \\
\text { acetonitrile containing } 0.1 \% \text { formic acid; Elution } \\
\text { profile: } 0-9.5 \mathrm{~min}, 1-100 \% \mathrm{~B} \text {; Flow rate: } \\
0.5 \mathrm{~mL} / \mathrm{min} \text {; Injection volume: } 5 \mu \mathrm{L}\end{array}$ & $35 / 9.5$ & [237] \\
\hline \multirow[t]{2}{*}{$\begin{array}{c}\text { Burdock } \\
\text { leaves }\end{array}$} & $\begin{array}{l}\text { Quercetin, cynarin, benzoic acid, quercitrin, caffeic acid, } \\
\text { luteolin, chlorogenic acid, } p \text {-coumaric acid, rutin, arctiin }\end{array}$ & \multirow{2}{*}{$\begin{array}{c}\text { BEH C18 }(150 \mathrm{~mm} \times \\
2.1 \mathrm{~mm} \mathrm{ID} \times 1.7 \mu \mathrm{m}) \\
\text { column/ PDA, } \\
\text { ESI-MS-MS }\end{array}$} & \multirow{2}{*}{$\begin{array}{l}\text { A: water containing } 0.1 \% \text { formic acid; B: } \\
\text { acetonitrile/methanol (20/80); Elution profile: } \\
0-10 \mathrm{~min}, 10-30 \% \mathrm{~B} ; 10-20 \mathrm{~min}, 30-50 \% \mathrm{~B} \text {; } \\
20-23 \mathrm{~min}, 50-70 \% \mathrm{~B} ; 23-25 \mathrm{~min}, 70-10 \% \mathrm{~B} \text {; } \\
\text { Flow rate: } 0.28 \mathrm{~mL} / \mathrm{min} ; \mathrm{NM}^{\mathrm{a}}\end{array}$} & $\mathrm{NM}^{\mathrm{a}} / 25$ & {$[114]$} \\
\hline & & & & & \\
\hline $\begin{array}{l}\text { Grape } \\
\text { extract }\end{array}$ & $\begin{array}{l}\text { Malvidin glucoside, delphinidin glucoside, cyanidin } \\
\text { glucoside, petunidin glucoside, peonidin glucoside, } \\
\text { malvidin acetylglucoside, delphinidin acetylglucoside, } \\
\text { cyanidin acetylglucoside, petunidin acetylglucoside, } \\
\text { peonidin acetylglucoside, malvidin coumarylglucoside }\end{array}$ & $\begin{array}{c}\text { Zorbax SB-C18 }(50 \mathrm{~mm} \\
\times 2.1 \mathrm{~mm} \mathrm{ID} \times 1.8 \mu \mathrm{m}) \\
\text { column } / \text { PDA }^{\mathrm{b}}, \mathrm{MS}-\mathrm{MS}\end{array}$ & $\begin{array}{l}\text { A: water containing 10\%; B: acetonitrile; Elution } \\
\text { profile: } 0-1.5 \mathrm{~min}, 10-13 \% \mathrm{~B} ; 1.5-4.5 \mathrm{~min}, 13- \\
15 \% \mathrm{~B} \text {; } 4.5-7.5 \mathrm{~min}, 15-22 \% \mathrm{~B} ; 7.5-15 \mathrm{~min}, 22 \% \\
\text { B; Flow rate: } 0.2 \mathrm{~mL} / \mathrm{min} \text {; Injection volume: } 1 \mu \mathrm{L}\end{array}$ & $\mathrm{NM}^{\mathrm{a}} / 15$ & [238] \\
\hline
\end{tabular}


Table 9. Cont

\begin{tabular}{|c|c|c|c|c|c|}
\hline Sample & Phenolic class & Column/Detector & Solvent/ Flow rate/ injection volume & $\begin{array}{l}\text { Temperature } \\
\left({ }^{\circ} \mathrm{C}\right) / \text { Detection } \\
\text { time (min) }\end{array}$ & Ref. \\
\hline $\begin{array}{l}\text { Stem Bark } \\
\text { of Acacia } \\
\text { confusa }\end{array}$ & $\begin{array}{c}(+) \text {-catechin, }(-) \text {-epicatechin, } 4 \beta-(2- \\
\text { aminoethylthio }) \text { catechin, } 4 \beta-(2 \text {-aminoethylthio }) \\
\text { epicatechin }\end{array}$ & $\begin{array}{c}\text { Hypersil ODS } \\
(250 \mathrm{~mm} \times 4.6 \mathrm{~mm} \\
\text { ID } \times 2.5 \mu \mathrm{m}) \text { column} / \\
\text { ESI-MS }^{\mathrm{e}}\end{array}$ & $\begin{array}{l}\text { A: water containing } 0.5 \% \text { trifluoroacetic acid; B: } \\
\text { acetonitrile containing } 0.5 \% \text { trifluoroacetic acid; Elution } \\
\text { profile: } 0-5 \mathrm{~min}, 3 \% \mathrm{~B} ; 5-15 \mathrm{~min}, 3 \%-9 \% \mathrm{~B} ; 15-45 \mathrm{~min} \text {, } \\
9 \%-16 \% \mathrm{~B} ; 45-60 \mathrm{~min}, 16 \%-60 \% \mathrm{~B} \text {; Flow rate: } 1 \mathrm{~mL} / \mathrm{min} \text {; } \\
\mathrm{NM}^{\mathrm{a}}\end{array}$ & Ambient/NM ${ }^{\mathrm{a}}$ & [239] \\
\hline Lettuce & $\begin{array}{c}\text { Caffeoyltartaric acid, } p \text {-coumaroyltartaric acid, } \\
\text { caffeoylquinic acid, chlorogenic acid, } p \text { - } \\
\text { coumaroylquinic acid, caffeoylmalic acid, } \\
\text { dicaffeoyltartaric acid, chicoric acid, } \\
p \text {-coumaroylcaffeoyltartaric acid, di- } p \text { - } \\
\text { coumaroyltartaric acid, quercetin-3- } O \text {-glucuronide, } \\
\text { 3,5-dicaffeoylquinic acid, quercetin } \\
\text { malonylglucoside }\end{array}$ & $\begin{array}{l}\text { HSS T3 }(100 \mathrm{~mm} \times \\
2.1 \mathrm{~mm} \text { ID } \times 1.8 \mu \mathrm{m}) \\
\text { column } / \mathrm{PDA}^{\mathrm{b}}, \text { ESI- } \\
\text { MS }^{\mathrm{e}}\end{array}$ & $\begin{array}{l}\text { A: water:methanol:formic acid (94.9:5.0:0.1); B: } \\
\text { methanol:water:formic acid } \\
\text { (60.0:39.9:/0.1); Elution profile: } 0-30 \mathrm{~min}, 100-50 \% \mathrm{~A} \text {; } \\
\text { Flow rate: } 0.5 \mathrm{~mL} / \mathrm{min} \text {; Injection volume: } 10 \mu \mathrm{L}\end{array}$ & $35 / \mathrm{NM}^{\mathrm{a}}$ & [240] \\
\hline $\begin{array}{l}\text { Cocoa and } \\
\text { Chocolate } \\
\text { products }\end{array}$ & Catechin, epicatechin & $\begin{array}{c}\text { diol-based }(250 \mathrm{~mm} \\
\times 4.6 \mathrm{~mm} \mathrm{ID} \times 5 \mu \mathrm{m}) \\
\text { FLD }^{\mathrm{d}}, \mathrm{MS}\end{array}$ & $\begin{array}{l}\text { A: acetonitrile:acetic acid (98:2); B: methanol:water:acetic } \\
\text { acid (95:3:2); 0-35 min, 100-60\% A; 35-39 min, 60\% A; } \\
\text { 39-41 min, } 60-0 \% \text { A; 41-47 min, 0.0\% A; 47-51 min, } \\
0-100 \% \text { A; Flow rate: } 1.0 \mathrm{~mL} / \mathrm{min} \text {; Injection volume: } 10 \mu \mathrm{L}\end{array}$ & $30 / 51$ & [241] \\
\hline $\begin{array}{c}\text { Wild } \\
\text { mushroom }\end{array}$ & $\begin{array}{l}\text { Benzoic acids, } p \text {-hydroxybenzoic, protocatechuic, } \\
\text { vanillic, cinnamic, } p \text {-coumaric acids }\end{array}$ & $\begin{array}{l}\text { Spherisorb RP C18 } \\
(150 \mathrm{~mm} \times 4.6 \mathrm{~mm} \\
\text { ID } \times 3 \mu \mathrm{m}) \text { column/ } \\
\text { PDA }^{\mathrm{b}}, \mathrm{ESI}^{-\mathrm{MS}^{\mathrm{e}}}{ }^{\mathrm{e}}\end{array}$ & $\begin{array}{l}\text { A: water containing } 2.5 \% \text { acetic acid; B: acetic acid } 2.5 \% \text { : } \\
\text { acetonitrile (90:10); C: acetonitrile; Elution profile: } 10 \mathrm{~min} \text {, } \\
100 \% \mathrm{~A} ; 10-20 \mathrm{~min}, 50 \% \mathrm{~A} \text { and } 50 \% \mathrm{~B} ; 20-35 \mathrm{~min}, 100 \% \mathrm{~B} \text {; } \\
35-45 \mathrm{~min}, 90 \% \mathrm{~B} \text { and } 10 \% \mathrm{C} ; 45-55 \mathrm{~min}, 70 \% \mathrm{~B} \text { and } 30 \% \\
\text { C; } 55-60 \mathrm{~min}, 50 \% \mathrm{~B} \text { and } 50 \% \mathrm{C} ; 60-65 \mathrm{~min}, 20 \% \mathrm{~B} \text { and } \\
80 \% \mathrm{C} \text {; } 65-70 \mathrm{~min}, 100 \% \mathrm{~A} \text {; Flow rate: } 0.50 \mathrm{~mL} / \mathrm{min} ; \mathrm{NM}^{\mathrm{a}}\end{array}$ & $25 / \mathrm{NM}^{\mathrm{a}}$ & [242] \\
\hline
\end{tabular}


Table 9. Cont

\begin{tabular}{|c|c|c|c|c|c|}
\hline Sample & Phenolic class & Column/Detector & Solvent/ Flow rate/ injection volume & $\begin{array}{l}\text { Temperature } \\
\left({ }^{\circ} \mathrm{C}\right) / \text { Detection } \\
\text { time (min) }\end{array}$ & Ref. \\
\hline Cocoa, apple & $\begin{array}{c}\text { Quercetin, phloridzin, clovamide, } \\
p \text {-coumaroylquinic acid, caffeoylquinic acid, } \\
\text { quercetin-3- } O \text {-galactoside, quercetin-3- } O \text { - } \\
\text { arabinoside, quercetin-3- } O \text {-xyloside, } \\
\text { dideoxyclovamide, quercetin-3- } O \text {-rhamnoside }\end{array}$ & 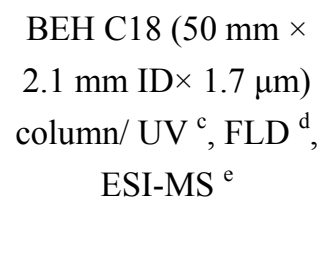 & $\begin{array}{c}\text { A: water containing } 0.1 \% \text { formic acid; B: acetonitrile; } \\
\text { Elution profile: } 0-0.25 \mathrm{~min}, 2 \% \mathrm{~B} ; 0.25-10.70 \mathrm{~min}, 2-18 \% \\
\text { B; } 10.70-18 \mathrm{~min}, 18-25 \% \mathrm{~B} ; 18-20.70 \mathrm{~min}, 25-100 \% \mathrm{~B} \text {; } \\
20.70-22.5 \mathrm{~min}, 100 \% \mathrm{~B} \text {; Flow rate: } 0.80 \mathrm{ml} / \mathrm{min} \text {; Injection } \\
\text { volume: } 2 \mu \mathrm{L}\end{array}$ & $50 / 22.5$ & [243] \\
\hline Bean & $\begin{array}{l}\text { Ferulic acid, } p \text {-coumaric acid, sinapic acid, caffeic } \\
\text { acid }\end{array}$ & $\begin{array}{c}\text { RP C18 Luna } \\
(150 \mathrm{~mm} \times 4.6 \mathrm{~mm} \\
\text { ID } \times 5 \mu \mathrm{m}) \text { column/ } \\
\text { PDA }^{\mathrm{b}}\end{array}$ & $\begin{array}{l}\text { A: water containing } 0.1 \% \text { formic acid; B: methanol; Elution } \\
\text { profile: } 0-50 \mathrm{~min}, 5-30 \% \mathrm{~B} ; 50-65 \mathrm{~min}, 30 \% \mathrm{~B} ; 65-75 \mathrm{~min} \text {, } \\
\qquad 30-100 \% \mathrm{~B} \text {; Flow rate: } 0.7 \mathrm{~mL} / \mathrm{min} ; \mathrm{NM}^{\mathrm{a}}\end{array}$ & $25 / 65$ & [244] \\
\hline $\begin{array}{l}\text { Green tea, } \\
\text { green coffee, } \\
\text { grapefruit }\end{array}$ & $\begin{array}{l}\text { Catechin, epigallocatechin gallate, epicatechin } \\
\text { gallate, epicatechine, gallocatechin, catechin } \\
\text { gallate, gallic acid, caffeine }\end{array}$ & $\begin{array}{l}\text { RP C18 Atlantis } \\
(100 \mathrm{~mm} \times 4.6 \mathrm{~mm} \\
\mathrm{ID} \times 3 \mu \mathrm{m}) / \mathrm{UV}\end{array}$ & $\begin{array}{l}\text { A: water containing } 0.1 \% \text { formic acid; B: methanol } \\
\text { containing } 0.1 \% \text { formic acid; Elution profile: } 0-5 \mathrm{~min}, 10 \% \\
\mathrm{~B} \text {; } 5-14 \mathrm{~min}, 10-20 \% \mathrm{~B} \text {; } 14-20 \mathrm{~min}, 20-50 \% \mathrm{~B} ; 20-22 \mathrm{~min} \text {, } \\
50-90 \% \mathrm{~B} ; 22-26 \mathrm{~min}, 90 \% \mathrm{~B} \text {; } 26-30 \mathrm{~min}, 90-10 \% \mathrm{~B} \text {; Flow } \\
\text { rate: } 0.5 \mathrm{~mL} / \mathrm{min} \text {; Injection volume: } 20 \mu \mathrm{L}\end{array}$ & $25 / \mathrm{NM}$ & {$[245]$} \\
\hline
\end{tabular}

${ }^{\mathrm{a}}$ Not mentioned; ${ }^{\mathrm{b}}$ Photodioide array detector; ${ }^{\mathrm{c}}$ Ultraviolet/ visible detector; ${ }^{\mathrm{d}}$ Fluorimetric detector; ${ }^{\mathrm{e}}$ Electroscopy ionization mass spectroscopy. 
The purification stage includes removing the interfering compounds from the crude extract with partitionable solvents and using open column chromatography or an adsorption-desorption process. Sephadex LH-20, polyamide, Amberlite, solid phase extraction (SPE) cartridges and styrenedivinylbenzene (XAD 4, XAD16, EXA-90, EXA 118, SP70), acrylic resins (XAD-7, EXA-31) are examples of regularly applied materials to purify phenolics from crude sample extracts [246-249]. However, in most studies, SPE is used for purification and partial concentration prior to separation using HPLC [58,250,251].

Acetonitrile and methanol, or their aqueous forms, are the dominant mobile phases utilized in HPLC quantification of phenolics [220,221,223]. In some cases, ethanol, tetrahydrofuran (THF) and 2-propanol have been used [252-254]. Attention is recommended to maintain the $\mathrm{pH}$ of the mobile phase in the range $\mathrm{pH} \mathrm{2-4}$ to avoid the ionization of phenolics during identification. Therefore, aqueous acidified mobile phases predominantly contain acetic acid but formic and phosphoric acids or phosphate, citrate and ammonium acetate buffers at low $\mathrm{pH}$ are also reported [24,222,223]. A gradient elution system is more commonly applied than an isocratic elution system [209].

Appropriate column selection is the other critical factor in identifying phenolics. Generally, based on the polarity, different classes of phenolics can be detected using a normal phase $\mathrm{C} 18$ or reversed phase (RP-C18) column 10-30 cm in length, 3.9-4.6 mm ID and 3-10 $\mu \mathrm{m}$ particle size [209,255]. However, new types of columns (monolithic and superficially porous particles columns) from 3-25 cm length, 1-4.6 mm ID and 1.7-10 $\mu \mathrm{m}$ particle size are employed in phenolic detection by advanced HPLC techniques like UHPLC (ultra-high pressure chromatography) and HTLC (high temperature liquid chromatography) and two-dimensional liquid chromatography (LC $\times$ LC) [212,256,257]. Most HPLC assays of phenolics are carried out at ambient column temperature. Recently, however, higher temperatures have also been recommended due to new columns and instrumentation [252,258]. HPLC running time is the other factor that influences the detection of phenolics and can range from 10 to $150 \mathrm{~min}$. Roggero et al. [259] emphasized that high reproducibility of results when long analysis times are employed requires constant temperature.

Phenolics are frequently identified using UV-VIS and photodiode array (PDA) detectors at wavelengths 190-380 nm [260,261] but fluorimetric (FLD) [262], colorometric arrays [263], PDA coupled with fluorescence [113] and chemical reaction detection techniques [264] are other methods used. Mass spectrometric (MS) detectors attached to high performance liquid chromatograph (HPLC-MS) [265,266], electrospray ionization mass spectrometry (ESI-MS) [217,267], matrix-assisted laser desorption/ionization mass spectrometry (MALDI-MS) [268,269], fast atom bombardment mass spectrometry (FAB-MS) [222,270] and electron impact mass spectrometry [270] have also been utilized for structural characterization and confirmation of different phenolic classes. HPLC coupled with MS detectors is highly sensitive and has the power to achieve high specificity due to the mass selectivity of detection [271]. HPLC-NMR and UHPLC are the other novel techniques to identify bioactive compounds in new sources of rare natural products [272-274]. The new trends in the analysis of phenolic compounds are hydrophilic interaction liquid chromatography (HILIC) as well as 2-dimensional liquid chromatography (2-D LC). HILIC may become more popular due to higher compatibility of applied mobile phase when linked to MS and enhanced accuracy to analyze polar components in complex matrices [275]. 2-D LC is a recent advance in chromatography that can afford separation and identification of structurally similar and minor compounds from complex matrices, 
enhancing peak capacity and selectivity [276]. A successful combination of 2-D LC $\times$ HILIC and 2-D LC $\times$ RP-LC has been used to detect polar and semi-polar fractions in traditional Chinese medicine. This combination of 2D-LC systems showed great potential to separate different components of a wide range of polarity from complex samples, which is not possible when using 1-D RPLC [277]. Table 9 presents some recent HPLC applications for determining different classes of phenolic compounds.

\subsection{Other Assays for Separation and Quantification of Phenolics}

Paper chromatography (PC) and thin-layer chromatography (TLC) are two partitioning techniques employed to separate phenolics in foods [182]. PC is a simple method and less utilized compared to HPLC and GC. PC has been used to separate and identify phenolic compounds from tea leaf with butanol/acetic acid/water as the mobile phase [278]. In other studies, flavonoids, phenolic acids and glycoflavones have been separated from three green leafy vegetables using PC [279].

TLC is a more powerful technique than PC to analyze phenolics, especially in crude plant extracts. Phenolics in crude plant extracts can be separated by a number of TLC techniques, which are cheap and provide for multiple detection on the same TLC plate in a short analysis time [120]. Sajewicz et al. [280] indicated that a silica gel TLC-based video imaging method is a valuable complementary fingerprint technique to identify phenolic acids and flavonoids fractions from different sage species. de Oliveira et al. [281] also utilized silica gel TLC to identify phenolic compounds from Baccharis trimera extract.

High-speed counter current chromatography (HSCCC) is a biphasic liquid-liquid partitioning method used to isolate and separate mixture components [28]. This unique technique has been widely used to purify and separate various natural compounds [282-285]. HSCCC separates compounds based on their partition coefficients between two solvent phases, which are determined by their hydrophobicity [286]. The method uses no solid support to allow permanent adsorption of sample compounds [287]. Furthermore, a crude extract can be applied to isolate and purify natural compounds without any preparation. Wang et al. [287] applied HSCCC to separate phenolics from a crude ethyl acetate extract of Halimodendron halodendron with chloroform-methanol-water-acetic acid $(4: 3: 2: 0.05, \mathrm{v} / \mathrm{v})$ as the two-phase solvent system. Three phenolic compounds were successfully separated by HSCCC. He et al. [288] separated and purified four minor phenolic acids from black currant samples. A two-phase solvent system consisting of ethyl acetate/water/- $n$-hexane/methanol $(15: 7: 5: 4, v / v)$ gave an efficient separation. The chemical structures of the purified phenolic acids were confirmed by HPLC-MS and NMR.

Capillary electrophoresis (CE) is high-resolution technique conducted with a solution of ions in a narrow capillary column. It is suitable to identify charged low and medium-molecular-weight compounds rapidly and efficiently with high-resolution and has low sample and reagent volume requirements [289]. There are few studies on the use of CE to separate and identify phenolics in plant materials [290-294]. Micellar electrokinetic chromatography (MEKC), capillary electro chromatography (CEC) and capillary zone electrophoresis (CZE) coupled with ultraviolet detection (UV), and electrochemistry detection or mass spectrometry detection (MS) are the most widely used techniques among the different types of CE separation [295-297]. Yuan et al. [298] developed MEKC 
to determine the main lignans in different parts of Schisandra sphenanthera. CE-ESI-microTOF-MS has been optimized to separate and identify phenolic compounds in buckwheat [299].

The other versatile chromatographic technique used to analyze and identify phenolics is supercritical fluid chromatography (SFC). Compared to other well-known chromatographic techniques (HPLC and GC), SFC has high separation efficiency, high-resolution power, short analysis time, is environmentally friendly and is compatible with different types of detectors [300-302]. Eight polyphenols in grape seed extract have been identified using SFC by Kamangerpour et al. [303]. Liu et al. [304] also identified polyhydroxyl flavonoids and quercetin by packed-column SCF.

The utility of both GC and HPLC coupled with MS has been shown repeatedly for the detection of phenolic compounds in a range of samples [201,305]. HPLC and GC are very useful, accurate and suitable methods to determine phenolics in various kinds of foods because they give very reliable results within short analysis times. Moreover, with progress in the development of HPLC techniques, such as 2-D LC and HILIC, simultaneous identification of phenolics with a wide range of polarities will be possible.

\section{Conclusions}

Cereal, vegetable and fruit consumption contributes to improved human health and lowers the risk of disease. These benefits may depend significantly on the phenolic content of these foods. The biology and health benefits of phenolics have lead researchers to discover, modify and utilize techniques for the extraction, separation and quantification of these compounds from natural sources. These methods need to be simple, rapid, environmentally friendly and comprehensive. This review has presented an overview of advanced extraction techniques to isolate and purify phenolics from plant-based sources, and provided information about some of the advanced separation and identification methods for plant phenolics.

\section{References}

1. Jin, D.; Mumper, R.J. Plant phenolics: Extraction, analysis and their antioxidant and anticancer properties. Review. Molecules 2010, 15, 7313-7352.

2. Wijngaard, H.H.; Rößle, C.; Brunton, N. A survey of Irish fruit and vegetable waste and byproducts as a source of polyphenolic antioxidants. Food Chem. 2009, 116, 202-207.

3. Hoye, A.T.; Davoren, J.E.; Wipf, P.; Fink, M.P.; Kagan, V.E. Targeting mitochondria. Acc. Chem. Res. 2008, 41, 87-97.

4. Mohanlal, S.; Parvathy, R.; Shalini, V.; Mohanan, R.; Helen, A.; Jayalekshmy, A. Chemical indices, Antioxidant activity and anti-inflammatory effect of extracts of the medicinal rice "Njavara" and staple varieties. J. Food Biochem. 2012, 36, 1-12.

5. Zhang, L.; Ravipati, A.S.; Koyyalamudi, S.R.; Jeong, S.; Reddy, N.; Smith, P.T.; Bartlett, J.; Shanmugam, K.; Münch, G.; Wu, M.J. Antioxidant and anti-inflammatory activities of selected medicinal plants containing phenolic and flavonoid compounds. J. Agric. Food Chem. 2011, 59, $12361-12367$. 
6. Jin, X.H.; Ohgami, K.; Shiratori, K.; Suzuki, Y.; Koyama, Y.; Yoshida, K.; Ilieva, I.; Tanaka, T.; Onoe, K.; Ohno, S. Effects of blue honeysuckle (Lonicera caerulea L.) extract on lipopolysaccharide-induced inflammation in vitro and in vivo. Exp. Eye Res. 2006, 82, 860-867.

7. Sawadogo, W.R.; Maciuk, A.; Banzouzi, J.T.; Champy, P.; Figadere, B.; Guissou, I.P.; Nacoulma, O.G. Mutagenic effect, Antioxidant and anticancer activities of six medicinal plants from Burkina Faso. Nat. Prod. Res. 2012, 26, 575-579.

8. Pieme, C.A.; Penlap, V.N.; Ngogang, J.; Costache, M. In vitro cytotoxicity and antioxidant activities of five medicinal plants of Malvaceae family from Cameroon. Environ. Toxicol. Pharmacol. 2010, 29, 223-228.

9. Ramos, S. Cancer chemoprevention and chemotherapy: Dietary polyphenols and signaling pathways. Mol. Nutr. Food Res. 2008, 52, 507-526.

10. Slivova, V.; Zaloga, G.; DeMichele, S.J.; Mukerji, P.; Huang, Y.S.; Siddiqui, R.; Harvey, K.; Valachovicova, T.; Sliva, D. Green tea polyphenols modulate secretion of urokinase plasminogen activator (uPA) and inhibit invasive behavior of breast cancer cells. Nutr. Cancer 2005, 52, 66-73.

11. Kusirisin, W.; Srichairatanakool, S.; Lerttrakarnnon, P.; Lailerd, N.; Suttajit, M.; Jaikang, C.; Chaiyasut, C. Antioxidative activity, Polyphenolic content and anti-glycation effect of some Thai medicinal plants traditionally used in diabetic patients. Med. Chem. 2009, 5, 139-147.

12. Scalbert, A.; Manach, C.; Remesy, C.; Morand, C. Dietary polyphenols and the prevention of diseases. Crit. Rev. Food Sci. Nutr. 2005, 45, 287-306.

13. Pedreschi, R.; Cisneros-Zevallos, L. Antimutagenic and antioxidant properties of phenolic fractions from Andean purple corn (Zea mays L.). J. Agric. Food Chem. 2006, 54, 4557-4567.

14. Gomez-Cordoves, C.; Bartolome, B.; Vieira, W.; Virador, V.M. Effects of wine phenolics and sorghum tannins on tyrosinase activity and growth of melanoma cells. J. Agric. Food Chem. 2001, 49, 1620-1624.

15. Diaz Napal, G.N.; Defago, M.; Valladares, G.; Palacios, S. Response of Epilachna paenulata to two flavonoids, Pinocembrin and quercetin, in a comparative study. J. Chem. Ecol. 2010, 36, 898-904.

16. Kennedy, D.O.; Wightman, E.L. Herbal extracts and phytochemicals: Plant secondary metabolites and the enhancement of human brain function. Adv. Nutr. 2011, 2, 32-50.

17. Zulak, K.; Liscombe, D.; Ashihara, H.; Facchini, P. Alkaloids. Plant Secondary Metabolism in Diet and Human Health; Blackwell Publishing: Oxford, UK, 2006.

18. Chung, I.M.; Park, M.R.; Chun, J.C.; Yun, S.J. Resveratrol accumulation and resveratrol synthase gene expression in response to abiotic stresses and hormones in peanut plants. Plant Sci. 2003, 164, 103-109.

19. Chirinos, R.; Betalleluz-Pallardel, I.; Huamán, A.; Arbizu, C.; Pedreschi, R.; Campos, D. HPLC-DAD characterisation of phenolic compounds from Andean oca (Oxalis tuberosa Mol.) tubers and their contribution to the antioxidant capacity. Food Chem. 2009, 113, 1243-1251.

20. Soto-Vaca, A.; Losso, J.N.; Xu, Z.; Finley, J.W. Review: Evolution of phenolic compounds from color and flavor problems to health benefits. J. Agric. Food Chem. 2012, Epub ahead of print.

21. Ferreira, O.; Pinho, S.P. Solubility of flavonoids in pure solvents. Ind. Eng. Chem. Res. 2012, 51, 6586-6590. 
22. Rong, T. Chemistry and biochemistry of dietary polyphenols, Review. Nutrients 2010, 2, 1231-1246.

23. Routray, W.; Orsat, V. Review: Microwave-assisted extraction of flavonoids. Food Bioprocess. Technol. 2012, 5, 409-424.

24. Stalikas, C.D. Review: Extraction, Separation, and detection methods for phenolic acids and flavonoids. J. Sep. Sci. 2007, 30, 3268-3295.

25. Pereira, D.M.; Valentão, P.; Pereira, J.A.; Andrade, P.B. Phenolics: From chemistry to biology. Molecules 2009, 2202-2211.

26. Vanholme, R.; Demedts, B.; Morreel, K.; Ralph, J.; Boerjarr, W. Lignin biosynthesis and structure. Plant. Physiol. 2010, 153, 895-905.

27. Baucher, M.; Monties, B.; Van Montagu, M.; Boerjan, W. Biosynthesis and genetic engineering of lignin. Crit. Rev. Plant Sci. 1998, 17, 125-197.

28. Naczk, M.; Shahidi, F. Review: Extraction and analysis of phenolics in food. J. Chromatogr. A 2004, 1054, 95-111.

29. Sejali, S.N.F.; Anuar, M.S. Effect of drying methods on phenolic contents of neem (Azadirachta indica) leaf powder. J. Herbs Spices Med. Plants 2011, 17, 119-131.

30. Giao, M.S.; Pereira, C.I.; Fonseca, S.C.; Pintado, M.E.; Malcata, F.X. Effect of particle size upon the extent of extraction of antioxidant power from the plants Agrimonia eupatoria, Salvia sp. and Satureja montana. Food Chem. 2009, 117, 412-416.

31. Weidner, S.; Powałka, A.; Karamać, M.; Amarowicz, R. Extracts of phenolic compounds from seeds of three wild grapevines - Comparison of their antioxidant activities and the content of phenolic compounds. Int. J. Mol. Sci. 2012, 13, 3444-3457.

32. Garcia-Salas, P.; Morales-Soto, A.; Segura-Carretero, A.; Fernández-Gutiérrez, A. Phenoliccompound-extraction systems for fruit and vegetable samples. Molecules 2010, 15, 8813-8826.

33. Agbangnan, P.C.; Tachon, D.C.; Dangou, J.; Chrostowska, A.; Fouquet, E.; Sohounhloue, D.C.K. Optimization of the extraction of sorghum's polyphenols for industrial production by membrane processes. Res. J. Res. Sci. 2012, 1, 1-8.

34. Verma, B.; Hucl, P.; Chibbar, R.N. Phenolic content and antioxidant properties of bran in 51 wheat cultivars. Cereal Chem. 2008, 85, 544-549.

35. Kalpana, K.; Kapil, S.; Harsh, P.S.; Bikram, S. Effects of extraction methods on phenolic contents and antioxidant activity in aerial parts of Potentilla atrosanguinea Lodd. and quantification of its phenolic constituents by RP-HPLC. J. Agric. Food Chem. 2008, 56, 10129-10134.

36. Casazza, A.A.; Aliakbarian, B.; Mantegna, S.; Cravotto, G.; Perego, P. Extraction of phenolics from Vitis vinifera wastes using non-conventional techniques. J. Food Eng. 2010, 100, 50-55.

37. Taha, F.S.; Mohamed, G.F.; Mohamed, S.H.; Mohamed, S.S.; Kamil, M.M. Optimization of the extraction of total phenolic compounds from sunflower meal and evaluation of the bioactives of chosen extract. Am. J. Food Technol. 2011, 6, 1002-1020.

38. Biesaga, M.; Pyrzynska, K. Stability of bioactive polyphenols from honey during different extraction methods. Food Chem. 2013, 136, 46-54.

39. Davidov-Pardo, G.; Arozarena Inigo Marın-Arroyo, M.R. Stability of polyphenolic extracts from grape seeds after thermal treatments. Eur. Food. Res. Technol. 2011, 232, 211-220. 
40. Naczk, M.; Amarowicz, R.; Zadernowski, R.; Shahidi, F. Antioxidant Capacity of Phenolics from Canola Hulls as Affected by Different Solvents. In Phenolic Compounds in Foods and Natural Health Products; Shahidi, F., Ho, C.T., Eds; Oxford University Press: New York, NY, USA, 2005; pp. 57-66.

41. Al-Farsi, M.; Lee, C.Y. Review: Nutritional and functional properties of dates. Crit. Rev. Food Sci. Nutr. 2008, 48, 877-887.

42. Pinelo, M.; Zornoza, B.; Meyer, A.S. Selective release of phenols from apple skin: Mass transfer kinetics during solvent and enzyme-assisted extraction. Sep. Purif. Technol. 2008, 63, 620-627.

43. Haghi, G.; Hatami, A. Simultaneous quantification of flavonoids and phenolic acids in plant materials by a newly developed isocratic high-performance liquid chromatography approach. J. Agric. Food Chem. 2010, 58, 10812-10816.

44. Vichapong, J.; Maliwan, S.; Voranuch, S.; Prasan, S.; Supalax, S. High performance liquid chromatographic analysis of phenolic compounds and their antioxidant activities in rice varieties. LWT-Food Sci. Technol. 2010, 43, 1325-1330.

45. Ayumi, H.; Masatsune, M.; Seiichi, H. Analysis of free and bound phenolics in rice. Food Sci. Technol. Res. 1999, 5, 74-79.

46. Nardini, M.; Cirillo, E.; Natella, F.; Mencarelli, D.; Comisso, A.; Scaccini, C. Detection of bound phenolic acidsprevention by ascorbic acid and ethylenediaminetetraacetic acid of degradation of phenolic acids during alkaline hydrolysis. Food Chem. 2002, 79, 119-124.

47. Weidner, S.; Amarowicz, R.; Karamac, M.; Dabrowski, G. Phenolic acids in caryopses of two cultivars of wheat, rye and triticale that display different resistance to pre-harvest sprouting. Eur. Food Res. Technol. 1999, 210, 109-113.

48. Macdonald, I.O.; Oludare, A.S.; Olabiyi, A. Phytotoxic and anti-microbial activities of flavonoids in Ocimum gratissimum. Life Sci. 2010, 7, 45-48.

49. Zhu, H.B.; Wang, Y.Z.; Liu, Y.X.; Xia, Y.L.; Tang, T. Analysis of flavonoids in Portulaca oleracea L. by UV-Vis spectrophotometry with comparative study on different extraction technologies. Food Anal. Meth. 2010, 3, 90-97.

50. Biesaga, M. Influence of extraction methods on stability of flavonoids. J. Chromatogr. A 2011, 1218, 2505-2512.

51. Tsimogiannis, D.; Samiotaki, M.; Panayotou, G.; Oreopoulou, V. Characterization of flavonoid subgroups and hydroxy substitution by HPLC-MS/MS. Molecules 2007, 12, 593-606.

52. Mattila, P.; Astola, J.; Kumpulainen, J. Determination of flavonoids in plant material by HPLC with diode-array and electro-array detections. J. Agric. Food Chem. 2000, 48, 5834-5841.

53. Wu, Y.; Wang, X.; Fan, E. Optimisation of ultrasound-assisted extraction of puerarin and total isoflavones from Puerariae lobatae Radix (Pueraria lobata (Wild.) Ohwi) with response surface methodology. Phytochem. Anal. 2012, 23, 513-519.

54. Patil, G.; Madhusudhan, M.C.; Ravindra Babu, B.; Raghavarao, K.S.M.S. Extraction, dealcoholization and concentration of anthocyanin from red radish. Chem. Eng. Process. 2009, 48, 364-369.

55. Amr, A.; Al-Tamimi, E. Stability of the crude extracts of Ranunculus asiaticus anthocyanins and their use as food colourants. Int. J. Food Sci. Tech. 2007, 42, 985-991. 
56. Awika, J.M.; Rooney, L.W.; Waniska, R.D. Anthocyanins from black sorghum and their antioxidant properties. Food Chem. 2005, 90, 293-301.

57. Kong, J.M.; Chia, L.S.; Goh, N.K.; Chia, T.F.; Brouillard, R. Analysis and biological activities of anthocyanins. Phytochemistry 2003, 64, 923-933.

58. Castaneda-Ovando, A.; de Lourdes Pacheco-Hernandez, M.; Paez-Hernandez Ma, E.; RodriguezGalan-Vidal, J.A.; Galan-Vidal, C.A. Review: Chemical studies of anthocyanins. Food Chem. 2009, 113, 859-871.

59. Bridgers, E.N.; Chinn, M.S.; Truong, V.-D. Extraction of anthocyanins from industrial purple-fleshed sweetpotatoes and enzymatic hydrolysis of residues for fermentable sugars. Ind. Crop. Prod. 2010, 32, 613-620.

60. Lee, J.; Finn, C.E.; Wrolstad, R.E. Anthocyanin pigment and total phenolic content of three vaccinium species native to the Pacific Northwest of North America. Hortscience 2004, 39, 959-964.

61. Kapasakalidis, P.G.; Rastall, R.A.; Gordon, M.H. Extraction of polyphenols from processed black currant (Ribes nigrum L.) residues. J. Agric. Food Chem. 2006, 54, 4016-4021.

62. Delgado-Vargas, F.; Paredes-Lopez, O. Natural Colorants for Food and Nutraceutical Uses; CRC Press: Boca Raton, FL, USA, 2002; p. 342.

63. Ju, Z.Y.; Howard, L.R. Subcritical water and sulfured water extraction of anthocyanins and other phenolics from dried red grape skin. J. Food Sci. 2005, 70, 270-276.

64. Cacace, J.E.; Mazza, G. Extraction of anthocyanins and other phenolics from black currants with sulfured water. J. Agric. Food Chem. 2002, 50, 5939-5946.

65. Nam-Young, K.; Min-Kyung, J.; Dong-Geun, L.; Ki, H.Y.; HyeJi, J.; Mihyang, K.; Sung, G.K.; Byung, H.Y.; Sang-Hyeon, L. Comparison of methods for proanthocyanidin extraction from pine (Pinus densiflora) needles and biological activities of the extracts. Nutr. Res. Pract. 2010, 4, $16-22$.

66. Xiaoyun, X.; Bijun, X.; Siyi, P.; Erning, Y.; Kexin, W.; Stefan, C.; Arnie, W.H.; Shan, R. A new technology for extraction and purification of proanthocyanidins derived from sea buckthorn bark. J. Sci. Food Agric. 2006, 86, 486-492.

67. Hernández-Jiménez, A.; Kennedy, J.A.; Bautista-Ortín, A.B.; Gómez-Plaza, E. Effect of ethanol on grape seed proanthocyanidin extraction. Am. J. Enol. Vitic. 2012, 63, 57-61.

68. Vatai, T.; Skerget, M.; Knez, Z. Extraction of phenolic compounds from elder berry and different grape marc varieties using organic solvents and/or supercritical carbon dioxide. J. Food Eng. 2009, 90, 246-254.

69. Yang, L.; Sun, X.; Yang, F.; Zhao, C.; Zhang, L.; Zu, Y. Application of ionic liquids in the microwave-assisted extraction of proanthocyanidins from Larix gmelini bark. Int. J. Mol. Sci. 2012, 13, 5163-5178.

70. Castro-Vargas, H.I.; Rodríguez-Varela, L.I.; Ferreira, S.R.S.; Parada-Alfonso, F. Extraction of phenolic fraction from guava seeds (Psidium guajava L.) using supercritical carbon dioxide and co-solvents. J. Supercrit. Fluids 2010, 51, 319-324.

71. Santana, C.M.; Ferrera, Z.S.; Torres Padrón, M.E.; Santana Rodríguez, J.J. Methodologies for the extraction of phenolic compounds from environmental samples: New approaches. Molecules 2009, 14, 298-320. 
72. Altuner, E.M.; Işlek, C.; Çeter, T.; Alpas, H. High hydrostatic pressure extraction of phenolic compounds from Maclura pomifera fruits. Afr. J. Biotechnol. 2012, 11, 930-937.

73. Liazid, A.; Palma, M.; Brigui, J.; Barroso, C.G. Investigation on phenolic compounds stability during microwave-assisted extraction. J. Chromatogr. A 2007, 1140, 29-34.

74. Lutria, D.L. Application of green chemistry principles for extraction of polylipids and phenolic compounds. Ind. J. Chem. 2006, 45, 2291-2296.

75. Aspé, E.; Fernández, K. The effect of different extraction techniques on extraction yield, total phenolic, and anti-radical capacity of extracts from Pinus radiata Bark. Ind. Crop. Prod. 2011, 34, 838-844.

76. Toma, M.; Vinatoru, M.; Paniwnyk, L.; Mason, T. Investigation of the effects of ultrasound on vegetal tissues during solvent extraction. Ultrason. Sonochem. 2001, 8, 137-142.

77. Vinatoru, M. An overview of the ultrasonically assisted extraction of bioactive principles from herbs. Ultrason. Sonochem. 2001, 8, 303-313.

78. Wang, L.; Weller, C.L. Recent advances in extraction of nutraceuticals from plants. Trends Food Sci. Technol. 2006, 17, 300-312.

79. Kivilompolo, M.; Hyotylainen, T. On-line coupled dynamic sonication-assisted extraction-liquid chromatography for the determination of phenolic acids in Lamiaceae herbs. J. Chromatogr. A 2009, 1216, 892-896.

80. Domeño, C.; Blasco, M.; Sánchez, C.; Nerín, C. A fast extraction technique for extracting polycyclic aromatic hydrocarbons (PAHs) from lichens samples used as biomonitors of air pollution: Dynamic sonication versus other methods. Anal. Chim. Acta 2006, 569, 103-112.

81. Blasco, M.; Domeño, C.; Nerín, C. Lichens biomonitoring as feasible methodology to assess air pollution in natural ecosystems: Combined study of quantitative PAHs analyses and lichen biodiversity in the Pyrenees Mountains. Anal. Bioanal. Chem. 2008, 391, 759-771.

82. Blasco, M.; Domeño, C.; Lopez , P.; Nerín, C. Behaviour of different lichen species as biomonitors of air pollution by PAHs in natural cosystems. J. Environ. Monit. 2011, 13, 2588-2596.

83. Luque-Garcia, J.L.; Luque de Castro, M.D. Where is microwave based analytical treatment for solid sample pre-treatment going? Trends Anal. Chem. 2003, 22, 90-99.

84. Lee, M.H.; Lin, C.C. Comparison of techniques for extraction of isoflavones from the root of Radix Puerariae: Ultrasonic and pressurized solvent extractions. Food Chem. 2007, 105, 223-228.

85. Lu, C.; Wang, H.; Lv, W.; Ma, C.; Lou, Z.; Xie, J.; Liu, B. Ionic liquid-based ultrasonic/microwave-assisted extraction combined with UPLC-MS-MS for the determination of tannins in Galla chinensis. Nat. Prod. Res. 2012, 26, 1842-1847.

86. Kamran Khan, M.; Abert-Vian, M.; Fabiano-Tixier, A.-S.; Dangles, O.; Chemat, F. Ultrasoundassisted extraction of polyphenols (flavanone glycosides) from orange (Citrus sinensis L.) peel. Food Chem. 2010, 119, 851-858.

87. Ma, Y.; Ye, X.; Fang, Z.; Chen, J.; Xu, G.; Liu, D. Phenolic compounds and antioxidant activity of extracts from ultrasonic treatment of Satsuma mandarin (Citrus unshiu Marc.) peels. J. Agric. Food Chem. 2008, 56, 5682-5690.

88. Rostagno, A.; Palma, M.; Barroso, C. Ultrasound-assisted extraction of soy isoflavones. J. Chromatogr. A 2003, 1012, 119-128. 
89. Zhang, H.F.; Yangb, X.H.; Wang, Y. Microwave assisted extraction of secondary metabolites from plants: Current status and future directions. Trends Food Sci. Technol. 2011, 22, 672-688.

90. Camel, V. Recent extraction techniques for solid matrices supercritical fluid extraction pressurised fluid extraction and microwave-assisted extraction: their potential and pitfalls. Analyst 2001, 126, 1182-1193.

91. Zuloaga, O.; Etxebarria, N.; Fernandez, L.A.; Madariaga, J.M. Optimization and comparison of microwave assisted extraction and Soxhlet extraction for the determination of polychlorinated biphenyls in soil samples using an experimental design approach. Talanta 1999, 50, 345-357.

92. Huie, C.W. A review of modern sample preparation techniques for the extraction and analysis of medicinal plants. Anal. Bioanal. Chem. 2002, 373, 23-30.

93. Mandal, V.; Mohan, Y.; Hemalatha, S. Microwave assisted extraction-An innovative and promising extraction tool for medicinal plant research. Pharmacogn. Rev. 2007, 1, 7-18.

94. Eskilsson, C.S.; Björklund, E. Analytical-scale microwave-assisted extraction. J. Chromatogr. A 2000, 902, 227-250.

95. Witayasinthana, W.; Shotipruk, A. Recovery of anti-cancer damnacanthal from roots of morinda citrifolia by microwave-assisted extraction. Sep. Sci.Technol. 2009, 44, 2942-2955.

96. Ajila, C.M.; Brar, S.K.; Verma, M.; Tyagi, R.D.; Godbout, S.; Valero, J.R. Extraction and analysis of polyphenols: recent trends. Crit. Rev. Biotech. 2011, 31, 227-249.

97. Venkatesh, M.; Raghavan, G. An overview of microwave processing and dielectric properties of agri-food materials. Biosys. Eng. 2004, 88, 1-18.

98. Vasu, S.; Palaniyappan, V.; Badami, S. A novel microwave-assisted extraction for the isolation of andrographolide from Andrographis paniculata and its in vitro antioxidant activity. J. Nat. Prod. 2010, 24, 1560-1567.

99. Xiao, W.; Han, L.; Shi, B. Microwave-assisted extraction of flavonoids from Radix astragali. Sep. Purif. Technol. 2008, 62, 614-618.

100. Hemwimon, S.; Pavasant, P.; Shotipruk, A. Microwave-assisted extraction of antioxidative anthraquinones from roots of Morinda citrifolia. Sep. Purif. Technol. 2007, 54, 44-50.

101. Nkhili, E.; Valerie, T.; El Hajji, H.; El Boustani, E.S.; Chemat, F.; Dangles, O. Microwaveassisted water extraction of green tea polyphenols. Phytochem. Anal. 2009, 20, 408-415.

102. Wang, L.; Qin, P.; Hu, Y. Study on the microwave-assisted extraction of polyphenols from tea. Front. Chem. Eng. Chin. 2010, 4, 307-313.

103. Song, J.; Li, D.; Liu, C.; Zhang, Y. Optimized microwaveassisted extraction of total phenolics (TP) from Ipomoea batatas leaves and its antioxidant activity. Innovat. Food Sci. Emerg. Tech. 2011, 12, 282-287.

104. Sutivisedsak, N.; Cheng, H.N.; Willett, J.L.; Lesch, W.C.; Tangsrud, R.R.; Biswas, A. Microwave-assisted extraction of phenolics from bean (Phaseolus vulgaris L.). Food Res. Int. 2010, 43, 516-519.

105. Inglett, G.E.; Rose, D.J.; Chen, D.; Stevenson, D.G.; Biswas, A. Phenolic content and antioxidant activity of extracts from whole buckwheat (Fagopyrum esculentum Moench) with or without microwave irradiation. Food Chem. 2010, 119, 1216-1219. 
106. Martino, E.; Ramaiola, I.; Urbano, M.; Bracco, F.; Collina, S. Microwave-assisted extraction of coumarin and related compounds from Melilotus officinalis (L.) Pallas as an alternative to Soxhlet and ultrasound-assisted extraction. J. Chromatogr. A 2006, 1125, 147-151.

107. Longares-Patron, A.; Canizares-Macias, M.P. Focused microwaves-assisted extraction and simultaneous spectrophotometric determination of vanillin and p-hydroxybenzaldehyde from vanilla fragans. Talanta 2006, 69, 882-887.

108. Liu, Z.; Wang, J.; Shen, P.; Wang, C.; Shen, Y. Microwave-assisted extraction and high-speed counter-current chromatography purification of ferulic acid from Radix Angelicae sinensis. Sep. Purif. Technol. 2006, 52, 18-21.

109. Gao, M.; Song, B.-Z.; Liu, C.-Z. Dynamic microwave-assisted extraction of flavonoids from Saussurea medusa Maxim cultured cells. Biochem. Eng. J. 2006, 32, 79-83.

110. Constance, C.; Lloyd, W.R.; Trust, B. Microwave-assisted extraction of bound phenolic acids in bran and flour fractions from sorghum and maize cultivars varying in hardness. J. Agric. Food Chem. 2012, 60, 4735-4742.

111. Gallo, M.; Ferracane, R.; Graziani, G.; Ritieni, A.; Fogliano, V. Microwave assisted extraction of phenolic compounds from four different spices. Molecules 2010, 15, 6356-6374.

112. Jiao, Y.; Zuo, Y. Ultrasonic extraction and HPLC determination of anthraquinones, aloeemodine, emodine, rheine, chrysophanol and physcione, in roots of Polygoni multiflori. Phytochem. Anal. 2009, 20, 272-278.

113. Rostagno, M.A.; Arrigo, M.D.; Martínez, J.A. Combinatory and hyphenated sample preparation for the determination of bioactive compounds in foods. TrAC-Trend. Anal. Chem. 2010, 29, $553-561$.

114. Lou, Z.X.; Wang, H.X.; Zhu, S.; Zhang, M.; Gao, Y.; Ma, C.Y.; Wang, Z.P. Improved extraction and identification by ultra performance liquid chromatography tandem mass spectrometry of phenolic compounds in burdock leaves. J. Chromatogr. A 2010, 1217, 2441-2446.

115. Xiao-Lan, C.; Jin-Yi, W.; Ping, L.; Lian-Wen, Q. Ultrasonic/microwave assisted extraction and diagnostic ion filtering strategy by liquid chromatography-quadrupole time-of-flight mass spectrometry for rapid characterization of flavonoids in Spatholobus suberectus. J. Chromatogr. A 2011, 1218, 5774-5786.

116. Lianfu, Z.; Zelong, L. Optimization and comparison of ultrasound/microwave assisted extraction (UMAE) and ultrasonic assisted extraction (UAE) of lycopene from tomatoes. Ultrason. Sonochem. 2008, 15, 731-737.

117. Lou, Z.; Wang, H.; Zhu, S.; Chen, S.; Zhang, M.; Wang, Z. Ionic liquids based simultaneous ultrasonic and microwave assisted extraction of phenolic compounds from burdock leaves. Anal. Chim. Acta 2012, 716, 28-33.

118. Huang, L.Y.; Cao, Y.Y.; Chen, G.N. Purification of quercetin in Anoectochilu roxburghii (wall) Lindl using UMAE by high-speed countercurrent chromatography and subsequent structure identification. Sep. Purif. Technol. 2008, 64, 101-107.

119. Bleve, M.; Ciurlia, L.; Erroi, E.; Lionetto, G.; Longoc, L.; Rescioa, L.; Schettino, T.; Vaspollo, G. An innovative method for the purification of anthocyanins from grape skin extracts by using liquid and sub-critical carbon dioxide. Sep. Purif. Technol. 2008, 64, 192-197. 
120. Ignat, I.; Volf, I.; Popa, V.I. A critical review of methods for characterisation of polyphenolic compounds in fruits and vegetables. Food Chem. 2011, 126, 1821-1835.

121. Nahar, L.; Sarker, S.D. Supercritical fluid extraction. Methods Biotechnol. 2005, 20, 47-76.

122. Khosravi Darani, K.; Mozafari, M.R. A review: Supercritical fluids technology in bioprocess industries. J. Biochem. Tech. 2009, 2, 144-152.

123. Wells, S.; DeSimone, J. $\mathrm{CO}_{2}$ technology platform: an important tools for environmental problem solving. Angew. Chem. Int. Ed. 2001, 40, 518-527.

124. Abbasi, H.; Rezaei, K.; Emamdjomeh, Z.; Ebrahimzadeh Mousavi, S.M. Effect of various extraction conditions on the phenolic contents of pomegranate seed oil. Eur. J. Lipid Sci. Technol. 2008, 110, 435-440.

125. Gelmez, N.; Kincal, N.S.; Yener, M.E. Optimization of supercritical carbon dioxide extraction of antioxidants from roasted wheat germ based on yield, total phenolic and tocopherol contents, and antioxidant activities of the extracts. J. Supercrit. Fluids 2009, 48, 217-224.

126. Maróstica Junior, M.R.; Leite, A.V.; Vicente Dragano, N.R. Supercritical fluid extraction and stabilization of phenolic compounds from natural sources-Review (supercritical extraction and stabilization of phenolic compounds). Open Chem. Eng. J. 2010, 4, 51-60.

127. Holliday, D.L. Phenolic compounds and antioxidant activity of oat bran by various extraction methods. Masters Thesis, Louisiana State University, LA, USA, December 2010.

128. Arlorio, M.; Coïsson, J.D.; Travaglia, F.; Varsaldi, F.; Miglio, G.; Lombardi, G.; Martelli, A. Antioxidant and biological activity of phenolic pigments from Theobroma cacao hulls extracted with supercritical $\mathrm{CO}_{2}$. Food Res. Int. 2005, 38, 1009-1014.

129. Leal, P.F.; Maia, N.B.; Carmello, Q.A.C.; Catharino, R.R.; Eberlin, M.N.; Meireles, M.A.A. Sweet basil (Ocimum basilicum) extracts obtained by supercritical fluid extraction (SFE): Global yields, Chemical composition, Antioxidant activity, and estimation of the cost of manufacturing. Food Bioprocess Technol. 2008, 1, 326-338.

130. Piantino, C.R.; Aquino, F.W.B.; Follegatti-Romero, L.A.; Cabral, F.A. Supercritical $\mathrm{CO}_{2}$ extraction of phenolic compounds from Baccharis dracunculifolia. J. Supercrit. Fluids 2008, 47, 209-214.

131. Goli, A.H.; Barzegar, M.; Sahari, M.A. Antioxidant activity and total phenolic Compounds of pistachio (Pistachia vera) hull extracts. Food Chem. 2005, 92, 521-525.

132. Wang, B.J.; Liu, C.T.; Tseng, C.Y.; Yu, Z.R. Antioxidant activity of Bupleurum kaoi Liu (Chao et Chuang) fractions fractionated by supercritical $\mathrm{CO}_{2}$. LWT-Food Sci. Technol. 2005, 38, 281-287.

133. Shan, B.; Xie, J.-H.; Zhu, J.-H.; Peng, Y. Ethanol modified supercritical carbon dioxide extraction of flavonoids from Momordica charantia L. and its antioxidant activity. Food Bioprod. Process. 2012, 90, 579-587.

134. Bimakr, M.; Abdul Rahman, R.; Saleena Taip, F.; Ganjloo, A.; Salleh, L.M.; Selamat, J.; Hamid, A.; Zaidul, I.S.M. Comparison of different extraction methods for the extraction of major bioactive flavonoid compounds from spearmint (Mentha spicata L.) leaves. Food Bioprod. Process. 2011, 89, 67-72. 
135. Liza, M.S.; Abdul Rahman, R.; Mandana, B.; Jinap, S.; Rahmat, A.; Zaidul, I.S.M.; Hamid, A. Supercritical carbon dioxide extraction of bioactive flavonoid from Strobilanthes crispus (Pecah Kaca). 2010, 88, 319-326.

136. Wang, L.; Yang, B.; Du, X.; Yi, C. Optimisation of supercritical extraction of flavonoids from Pueraria lobata. Food Chem. 2008, 108, 737-741.

137. Kronholm, J.; Hartonen, K.; Riekkola, M.L. Analytical extractions with water at elevated temperatures and pressures. TrAC-Trends Anal. Chem. 2007, 26, 396-412.

138. Herrero, M.; Cifuentes, A.; Ibanez, E. A review: Sub- and supercritical fluid extraction of functional ingredients from different natural sources: Plants, Food-byproducts, Algae and microalgae. Food Chem. 2006, 98, 136-148.

139. Moran, J.; Shapiro, H.N. Fundamentals of Engineering Thermodynamics, 5th ed.; John Wiley \& Sons Ltd: West Sussex, UK, 2006.

140. Fernandez, D.P.; Goodwin, A.R.H.; Lemmon, E.W.; Levelt-Sengers, J.M.H.; Williams, R.C. A formulation for the static permittivity of water and steam at temperatures atures from $238 \mathrm{~K}$ to $873 \mathrm{~K}$ at pressures up to $1200 \mathrm{MPa}$, Including derivatives and Debye-Hückel coefficients. J. Phys. Chem. 1997, 26, 1126-1166.

141. Miller, D.J.; Hawthorne, S.B. Solubility of liquid organic flavor and fragance compounds in subcritical (hot/liquid) water from 298 to 473 K. J. Chem. Eng. Data 2000, 45, 315-318.

142. Luque-Rodríguez, J.M.; Luque de Castro, M.D.; Pérez-Juan, P. Dynamic superheated liquid extraction of anthocyanins and other phenolics from red grape skins of wine making residues. Bioresource Technol. 2007, 98, 2705-2713.

143. Eikani, M.H.; Golmohammad, F.; Rowshanzamir, S. Subcritical water extraction of essential oils from coriander seeds (Coriandrum sativum L.). J. Food Eng. 2006, 80, 735-740.

144. Pongnaravane, B.; Goto, M.; Sasaki, M.; Anekpankul, T.; Pavasant, P.; Shotipruk, A. Extraction of anthraquinones from roots of Morinda citrifolia by pressurized hot water: Antioxidant activity of extracts. J. Supercrit. Fluids 2006, 37, 390-396.

145. He, L.; Zhang, X.; Xu, H.; Xu, C.; Yuan, F.; Knez, Z.E.; Novak, Z.; Gao, Y. Subcritical water extraction of phenolic compounds from pomegranate (Punica granatum L.) seed residues and investigation into their antioxidant activities with HPLC-ABTS •+ assay. Food. Bioprod. Process. 2012, 90, 215-223.

146. Khuwijitjaru, P.; Sayputikasikorn, N.; Samuhasaneetoo, S.; Penroj, P.; Siriwongwilaichat, P.; Adachi, S. Subcritical water extraction of flavoring and phenolic compounds from cinnamon bark (Cinnamomum zeylanicum). J. Oleo Sci. 2012, 61, 349-355.

147. Singh, P.P.; Saldaña, M.D.A. Subcritical water extraction of phenolic compounds from potato peel. Food. Res. Int. 2011, 44, 2452-2458.

148. Cynthia, F.; Ngoc, Y.T.-T.; Novy, S.K.; Yi-Hsu, J. Release of phenolic acids from defatted rice bran by subcritical water treatment. J. Sci. Food Agric. 2010, 90, 2576-2581.

149. Rangsriwong, P.; Rangkadilok, N.; Satayavivad, J.; Gotoc, M.; Shotipruk, A. Subcritical water extraction of polyphenolic compounds from Terminalia chebula Retz. fruits. Sep. Purif. Technol. 2009, 66, 51-56. 
150. Budrat, P.; Shotipruk, A. Extraction of phenolic compounds from fruits of bitter melon (Momordica charantia) with subcritical water extraction and antioxidant activities of these extracts. Chiang Mai J. Sci. 2008, 35, 123-130.

151. Rodríguez-Meizoso, I.; Marin, F.R.; Herrero, M.; Señorans, F.J.; Reglero, G.; Cifuentes, A.; Ibáñez, E. Subcritical water extraction of nutraceuticals with antioxidant activity from oregano. Chemical and functional characterization. J. Pharmaceut. Biomed. 2006, 41, 1560-1565.

152. Etoh, H.; Ohtaki, N.; Kato, H.; Kulkarni, A.; Morita, A. Sub-critical water extraction of residual green tea to produce a roasted green tea-like extract. Biosci. Biotechnol. Biochem. 2010, 74, $858-860$.

153. Zhang, S.; Xi, J.; Wang, C. High hydrostatic pressure extraction of flavonoids from propolis. J. Chem. Technol. Biot. 2005, 80, 50-54.

154. Rastogi, N.K.; Angersbach, A.; Knorr, D. Food Preservation Technology; CRC Press: New York, NY, USA, 2003.

155. Yan, H.X. Separation Engineering. China Petrochemical Press: Beijing, China, 2002.

156. Richard, J.S. High Pressure Phase Behaviour of Multi Component Fluid Mixtures; Elsevier: Amsterdam, The Netherland, 1992.

157. Smith, R.M. Extractions with superheated water. J. Chromatogr. A 2002, 975, 31-46.

158. Ramos, L.; Kristenson, E.M.; Brinkman, U.A.T. Current use of pressurised liquid extraction and subcritical water extraction in environmental analysis. J. Chromatogr. A 2002, 975, 3-29.

159. Jun, X.; Deji, S.; Shou, Z.; Bingbing, L.; Ye, L.; Zhang, R. Characterization of polyphenols from green tea leaves using a high hydrostatic pressure extraction. Int. J. Pharm. 2009, 382, 139-143.

160. Corrales, M.; Toepfl, S.; Butz , P.; Knorr , D.; Tauscher, B. Extraction of anthocyanins from grape by-products assisted by ultrasonics, high hydrostatic pressure or pulsed electric fields: A comparison. Innov. Food Sci. Emerg. Technol. 2008, 9, 85-91.

161. Queiroz, C.; Moreira, F.F.; Lavinas, F.C.; Lopes, M.L.M.; Fialho, E.; Valente-Mesquita, V.L. Effect of high hydrostatic pressure on phenolic compounds, ascorbic acid and antioxidant activity in cashew apple juice. High Pressure Res. 2010, 30, 507-513.

162. Puértolas, E.; Luengo, E.; Álvarez, I.; Raso, J. Improving mass transfer to soften tissues by pulsed electric fields: Fundamentals and applications. Annu. Rev. Food Sci. Technol. 2012, 3, 263-282.

163. Toepfl, S.; Mathys, A.; Heinz, V.; Knorr, D. Review: Potential of high hydrostatic pressure and pulsed electric fields for energy efficient and environmentally friendly food processing. Food Rev. Int. 2006, 22, 405-423.

164. Kannan, V. Extraction of bioactive compounds from whole red cabbage and beetroot using pulsed electric fields and evaluation of their functionality. Masters Thesis, University of Nebraska, Lincoln, NE, USA, May 2011.

165. Odriozola-Serrano, I.; Soliva-Fortuny, R.; Martín-Belloso, O. Phenolic acids, flavonoids, vitamin $\mathrm{C}$ and antioxidant capacity of strawberry juices processed by high-intensity pulsed electric fields or heat treatments. Eur. Food Res. Technol. 2008, 228, 239-248.

166. López, N.; Puértolas, E.; Condón, S.; Álvarez, I.; Raso, J. Effects of pulsed electric fields on the extraction of phenolic compounds during the fermentation of must of Tempranillo grapes. Innov. Food Sci. Emerg. Technol. 2008, 9, 477-482. 
167. Grimi, N.; Nikolai, I.L.; Eugene, V.; Jean, V. Effect of a pulsed electric field treatment on expression behavior and juice quality of chardonnay grape. Food Biophys. 2009, 4, 191-198.

168. Delsart, C.; Ghidossi, R.; Poupot, C.; Cholet, C.; Grimi, N.; Vorobiev, E.; Milisic, V.; Mietton, M.P. Enhanced extraction of phenolic compounds from Merlot grapes by pulsed electric field treatment. Am. J. Enol. Vitic. 2012, 63, 205-211.

169. Turk, M.F.; Baron, A.; Eugene, V. Effect of pulsed electric fields treatment and mash size on extraction and composition of apple juices. J. Agric. Food Chem. 2010, 58, 9611-9616.

170. Wibisono, R.; Zhang, J.; Saleh, Z.; Stevenson, D.E.; Joyce, N.I. Optimization of accelerated solvent extraction for screening of the health benefits of plant food materials. Health 2009, 1 , 220-230.

171. Richter, B.E.; Jones, B.A.; Ezzell, J.L.; Porter, N.L.; Avdalovic, N.; Pohl, C. Accelerated solvent extraction: A technique for sample preparation. Ann. Chem. 1996, 68, 1033-1039.

172. Pinelo, M.; Meyer, A.S. Enzyme- assisted extraction of antioxidants: Release of phenols from vegetal matrixes. Elec. J. Env. Agric. Food Chem. 2008, 7, 3217-3220.

173. Pinelo, M.; Arnous, A.; Meyer, A.S. Upgrading of grape skins: significance of plant cell-wall structural components and extraction techniques for phenol release. Trends Food Sci. Technol. 2006, 17, 579-590.

174. Le Bourvellec, C.; Guyot, S.; Renard, C.M.G.C. Interactions between apple (Malus x domestica Borkh.) polyphenol and cell walls modulate the extractability of polysaccharides. Carbohyd. Polym. 2009, 75, 251-561.

175. Laroze, L.; Soto, C.; Zúñiga, M.E. Phenolic antioxidants extraction from raspberry wastes assisted by-enzymes. Electron. J. Biotechnol. 2010, 13, 1-11.

176. Maier, T.; Goppert, A.; Kammerer, D.R.; Schieber, A.; Carle, R. Optimization of a process for enzyme-assisted pigment extraction from grape (Vitis vinifera L.) pomace. Eur. Food Res. Technol. 2008, 227, 267-275.

177. Min, J.Y.; Kang, S.M.; Park, D.J.; Kim, Y.D.; Jung, H.N.; Yang, J.K.; Seo, W.T.; Kim, S.W.; Karigar, C.S.; Choi, M.S. Enzymatic release of ferulic acid from Ipomoea batatas L. (sweet potato) stem. Biotechnol. Bioproc. E 2006, 11, 372-376.

178. Hong, V.L.; Van Viet, M.L. Comparison of enzyme-assisted and ultrasound-assisted extraction of vitamin $\mathrm{C}$ and phenolic compounds from acerola (Malpighia emarginata DC.) fruit. Int. J. Food Sci. Tech. 2012, 47, 1206-1214.

179. Rong, T.; Yang, R. Optimization of a new mobile phase to know the complex and real polyphenolic composition: Towards a total phenolic index using high-performance liquid chromatography. J. Chromatogr. A 2003, 1018, 29-40.

180. Liu, Q.; Cai, W.; Shao, X. Determination of seven polyphenols in water by high performance liquid chromatography combined with preconcentration. Talanta 2008, 77, 679-683.

181. Lapornik, B.; Prosek, M.; Golc, W.A. Comparison of extracts prepared from plant by-products using different solvents and extraction time. J. Food Eng. 2005, 71, 214-222.

182. Naczk, M.; Shahidi, F. Phenolics in cereals, fruits and vegetables: Occurrence, extraction and analysis. J. Pharmaceut. Biomed. Anal. 2006, 41, 1523-1542.

183. Box, J.D. Investigation of the Folin-Ciocalteu phenol reagent for the determination of polyphenolic substances in natural waters. Water Res. 1983, 17, 511-525. 
184. Huang, W.; Xue, A.; Niu, H.; Jia, Z.; Wang, J. Optimised ultrasonic-assisted extraction of flavonoids from Folium eucommiae and evaluation of antioxidant activity in multi-test systems in vitro. Food Chem. 2009, 114, 1147-1154.

185. Fernandes, A.J.D.; Ferreira, M.R.A.; Randau, K.P.; De Souza, T.P.; Soares, L.A.L. Total flavonoids content in the raw material and aqueous extractives from Bauhinia monandra Kurz (Caesalpiniaceae). Sci. World J. 2012, 2012, 1-7.

186. Abeynayake, S.W.; Panter, S.; Mouradov, A.; Spangenberg, G. A high-resolution method for the localization of proanthocyanidins in plant tissues. Plant Method. 2011, 7, 1-6.

187. Hartzfeld, P.W.; Forkner, R.; Hunter, M.D.; Hagerman, A.E. Determination of hydrolyzable tannins (gallotannins and ellagitannins) after reaction with potassium iodate. J. Agric. Food Chem. 2002, 50, 1785-1790.

188. Kobs, L. Dietary Polyphenolic Intake from Acrons and Acron Meal. Masters Thesis, The University of Georgia, GA, USA, May 2008.

189. Porter, L.J.; Hrstich, L.N.; Chan, B.G. The conversion of procyanidins and prodelphinidins to cyanidin and delphinidin. Phytochemistry 1986, 25, 223-230.

190. Hagerman, A.E.; Butler, L.G. Protein Precipitation Method for Quantitative-Determination of Tannins. J. Agric. Food Chem. 1978, 26, 809-812.

191. Sarneckis, C.; Dambergs, R.G.; Jones, P.; Mercurio, M.D.; Herderich, M.J.; Smith, P.A. Quantification of condensed tannins by precipitation with methyl cellulose: Development and validation of an optimized tool for grape and wine analysis. Aust. J. Grape Wine Res. 2006, 12, 39-49.

192. Mercurio, M.D.; Dambergs, R.G.; Herderich, M.J.; Smith, P.A. High throughput analysis of red wine and grape phenolics - Adaption and validation of methyl cellulose precipitable tannin assay and modified somers color assay to a rapid 96 well plate format. J. Agric. Food Chem. 2007, 55, $4651-4657$.

193. Inoue, K.H.; Hagerman, A.E. Determination of gallotannin with rhodanine. Anal. Biochem. 1988, 169, 363-369.

194. Wilson, T.C.; Hagerman, A.E. Quantitative determination of ellagic acid. J. Agric. Food Chem. 1990, 38, 1678-1683.

195. Jun, X.; Shouqin, Z. Antioxactivity of ethanolic extract of propolis by hydrostatic pressure extraction. Int. J. Food Sci. Tech. 2007, 42, 1350-1356.

196. Marghtas, L.A.; Mihai, C.M.; Chirila, F.; Dezmirean, D.S.; Fit, N. The study of the antimicrobial activity of Transylvanian (Romanian) propolis. Not. Bot. Hort. Agrobot. Cluj. 2010, 38, 40-44.

197. Giusti, M.M.; Wrolstad, R.E. Acylated anthocyanins from edible sources and their applications in food systems. Biochem. Eng. J. 2003, 14, 217-225.

198. Welch, C.R.; Wu, Q.; Simon, J.E. Recent advances in anthocyanin analysis and characterization. Curr. Anal. Chem. 2008, 4, 75-101.

199. Martin, J.G.P.; Porto, E.; Corrêa, C.B.; De Alencar, S.M.; Da Gloria, E.M.; Cabral, I.S.R.; De Aquino, L.M. Antimicrobial potential and chemical composition of agro-industrial wastes. J. Nat. Prod. 2012, 5, 27-36. 
200. Shadkami, F.; Estevez, S.; Helleur, R. Analysis of catechins and condensed tannins by thermally assisted hydrolysis/methylation-GC/MS and by a novel two step methylation. J. Anal. Appl. Pyrolysis. 2009, 85, 54-65.

201. Proestos, C.; Boziaris, I.S.; Nychas, G.-J.E.; Komaitis, M. Analysis of flavonoids and phenolic acids in Greek aromatic plants: Investing ation of their antioxidant capacity and antimicrobial activity. Food Chem. 2006, 95, 664-671.

202. Liggins, J.; Bluck, L.J.C.; Coward, A.; Bingham, S.A. Extraction and quantification of daidzein and genistein in food. Anal. Biochem. 1998, 264, 1-7.

203. Siess, M.H.; Le Bon, A.M.; Canivenc-Lavier, M.C.; Amiot, M.J.; Sabatier, S.; Aubert, S.Y.; Suschetet, M. Flavonoids of honey and propolis: characterization and effects on hepatic drug-metabolizing enzymes and benzo[a]pyrene-DNA binding in rats. J. Agric. Food Chem. 1996, 44, 2297-2301.

204. Wang, L.F.; Kim, D.M.; Lee, C.Y. Effects of heat processing and storage on flavanols and sensory qualities of green tea beverage. J. Agric. Food Chem. 2000, 48, 4227-4232.

205. Smolarz, H.D. Application of GC-MS method for analysis of phenolic acids and their esters in chloroformic extracts from some taxons of Polygonum L. genus. Chem. Anal. 2001, 46, 439-444.

206. Waksmundzka-Hajnos, M. Chromatographic separations of aromatic carboxylic acids. J. Chromatogr. B 1998, 717, 93-118.

207. Husek, P. Fast derivatization and GC analysis of phenolic acids. Chromatographia 1992, 34, 621-626.

208. Zadernowski, R.; Czaplicki, S.; Naczk, M. Phenolic acid profiles of mangosteen fruits (Garcinia mangostana). Food Chem. 2009, 112, 685-689.

209. Robbins, R.J. Phenolic acids in foods: An overview of analytical methodology. J. Agric. Food Chem. 2003, 51, 2866-2887.

210. Pereira, A.D.S.; Padilha, M.C.; Neto, F.R.D.A. Two decades of high temperature gas chromatography (1983-2003): What'S next? Microchem. J. 2004, 77, 141-149.

211. Deslaurien, I. Recovery, separation and characterization of phenolic compounds and flavonids from maple products. Masters Thesis, McGill University, Montreal, Québec, Canada, March 2000.

212. Kalili, K.M.; de Villiers, A. Recent developments in the HPLC separation of phenolic compounds. J. Sep. Sci. 2011, 34, 854-876.

213. Flamini, R. Mass spectrometry in grape and wine chemistry. Part I: Polyphenols. Mass Spectrom. Rev. 2003, 22, 218-250.

214. Merken, H.M.; Beecher, G.R. Review: Measurement of food flavonoids by highperformance liquid chromatography. J. Agric. Food Chem. 2000, 48, 577-599.

215. Kuskoski , E.M.; Rios, J.J.; Bueno, J.M.; Fett, R.; Troncoso, A.M.; Asuero , A.G. Capillary gas chromatography-mass spectrometry (CGC-MS) analysis and antioxidant activities of phenolic and components of guarana and derivatives. Open Anal. Chem. J. 2012, 6, 1-8.

216. Khallouki, F.; Haubner, R.; Erben, G.; Ulrich, C.M.; Owen, R.W. Phytochemical composition and antioxidant capacity of various botanical parts of the fruits of Prunus domestica L. from the Lorraine region of Europe. Food Chem. 2012, 133, 697-706.

217. Wang, C.; Zuo, Y. Ultrasound-assisted hydrolysis and gas chromatography-mass spectrometric determination of phenolic compounds in cranberry products. Food Chem. 2011, 128, 562-568. 
218. Esmaeili , N.; Ebrahimzadeh, H.; Abdi, K.; Safarian, S. Determination of some phenolic compounds in Crocus sativus L. corms and its antioxidant activities study. Pharmacogn. Mag. 2011, 7, 74-80.

219. Salomão, K.; Dantas, A.P.; Borba, C.M.; Campos, L.C.; Machado, D.G.; Aquino Neto, F.R.; De Castro, S.L. Chemical composition and microbicidal activity of extracts from Brazilian and Bulgarian propolis. Appl. Microbiol. 2004, 38, 87-92.

220. Zarena, A.S.; Udaya Sankar, K. Phenolic acids, flavonoid profile and antioxidant activity in mangosteen (Garcina mangostana L.) pericarp. J. Food Biochem. 2011, 36, 627-633.

221. Qin, C.; Li, Y.; Niu, W.; Ding, Y.; Zhang, R.; Shang, X. Analysis and characterisation of anthocyanins in mulberry fruit. Czech J. Food Sci. 2010, 28, 117-126.

222. Lee, J.; Rennaker, C.; Wrolstad, R.E. Correlation of two anthocyanin quantification methods: HPLC and spectrophotometric methods. Food Chem. 2008, 110, 782-786.

223. Diagone, C.A.; Colombo, R.; Lancas, F.M.; Yariwake, J.H. CZE/PAD and HPLC-UV/PAD profile of flavonoids from Maytenus aquifolium and Maytenus ilicifolia "espinheira santa" leaves extracts. Chromatogr. Res. Int. 2012, 2012, doi:10.1155/2012/691509.

224. Hoang, N.T.T.; Golding, J.B.; Wilkes, M.A. The effect of postharvest 1-MCP treatment and storage atmosphere on 'Cripps Pink' apple phenolics and antioxidant activity. Food Chem. 2011, 127, 1249-1256.

225. Simirgiotis, M.J.; Silva, M.; Becerra, J.; Schmeda-Hirschmann, G. Direct characterisation of phenolic antioxidants in infusions from four Mapuche medicinal plants by liquid chromatography with diode array detection (HPLC-DAD) and electrospray ionisation tandem mass spectrometry (HPLC-ESI-MS). Food Chem. 2012, 131, 318-327.

226. Rzeppa, S.; Von Bargen, C.; Bittner, K.; Humpf, H.-U. Analysis of flavan-3-ols and procyanidins in food samples by reversed phase high-performance liquid chromatography coupled to electrospray ionization tandem mass spectrometry (RP-HPLC-ESI-MS/MS). J. Agric. Food Chem. 2011, 59, 10594-10603.

227. Chen, S.; Wu, B.-H.; Fang, J.-B.; Liua, Y.-L.; Zhang, H.-H.; Fang, L.-C.; Guan, L.; Li, S.-H. Analysis of flavonoids from lotus (Nelumbo nucifera) leaves using high performance liquid chromatography/photodiode array detector tandem electrospray ionization mass spectrometry and an extraction method optimized by orthogonal design. J. Chromatogr. A 2012, 1227, 145-153.

228. Muller, D.; Schantz, M.; Richling, E. High performance liquid chromatography analysis of anthocyanins in bilberries (Vaccinium myrtillus L.), blueberries (Vaccinium corymbosum L.), and corresponding juices. J. Food Sci. 2012, 77, 340-345.

229. Jalili, A.; Sadeghzade, A. Comparative phenolic profile of Persian walnut (Juglans regia L.) leaves cultivars grown in Iran. Afr. J. Biochem. Res. 2012, 6, 33-38.

230. Heinio, R.-L.; Liukkonena, K.-H.; Myllymaki, O.; Pihlavac, J.-M.; Adlercreutzd, H.; Heinonend, S.-M.; Poutanen, K. Quantities of phenolic compounds and their impacts on the perceived flavour attributes of rye grain. J. Cereal Sci. 2008, 47, 566-575.

231. Mousavinejad, G.; Emam-Djomeh, Z.; Rezaei, K.; Haddad Khodaparast, M.H. Identification and quantification of phenolic compounds and their effects on antioxidant activity in pomegranate juices of eight Iranian cultivars. Food Chem. 2009, 115, 1274-1278. 
232. Kelebek, H.; Selli, S. Determination of volatile, phenolic, organic acid and sugar components in a Turkish cv. Dortyol (Citrus sinensis L. Osbeck) orange juice. J. Sci. Food. Agric. 2011, 91, 1855-1862.

233. Gómez-Caravaca, A.M.; Iafelice, G.; Lavini, A.; Pulvento, C.; Caboni, M.F.; Marconi, E. Phenolic compounds and saponins in quinoa samples (Chenopodium quinoa Willd.) grown under different saline and nonsaline irrigation regimens. J. Agric. Food Chem. 2012, 60, 4620-4627.

234. Park , Y.S.; Jeon, M.H.; Hwang, H.J.; Park, M.R.; Lee, S.-H.; Kim, S.G.; Kim , M. Antioxidant activity and analysis of proanthocyanidins from pine (Pinus densiflora) needles. Nutr. Res. Pract. 2011, 5, 281-287.

235. Zitka, O.; Sochor, J.; Rop, O.; Skalickova, S.; Sobrova, P.; Zehnalek, J.; Beklova, M.; Krska, B.; Adam, V.; Kizek, R. Comparison of various easy-to-use procedures for extraction of phenols from apricot fruits. Molecules 2011, 16, 2914-2936.

236. Zimmermann, B.F.; Walch, S.G.; Tinzoh, L.N.; Stühlinger, W.; Lachenmeier, D.W. Rapid UHPLC determination of polyphenols in aqueous infusions of Salvia officinalis L. (sage tea). J. Chromatogr. B 2011, 879, 2459-2464.

237. Arraez-Roman, D.; Fu, S.; Sawalha, S.M.S.; Segura- Carretero, A.; Fernandez-Gutierrez, A. HPLC/CE-ESI-TOF-MS methods for the characterization of polyphenols in almond skin extracts. Electrophoresis 2010, 31, 2289-2296.

238. Pati, S.; Liberatore, M.T.; Gambacorta, G.; Antonacci, D.; La Notte, E. Rapid screening for anthocyanins and anthocyanin dimers in crude grape extracts by high performance liquid chromatography coupled with diode array detection and tandem mass spectrometry. J. Chromatogr. A 2009, 1216, 3864-3868.

239. Wei, S.-D.; Zhou, H.-C.; Lin, Y.-M. Antioxidant activities of fractions of polymeric procyanidins from stem bark of Acacia confuse. Int. J. Mol. Sci. 2011, 12, 1146-1160.

240. Ribas Agustí, A.; Gratacós Cubarsí, M.; Sárraga, C.; García Regueiro, J.A.; Castellari, M. Analysis of eleven phenolic compounds including novel $p$-coumaroyl derivatives in lettuce (Lactuca sativa L.) by ultra high performance liquid chromatography with photodiode array and mass spectrometry detection. Phytochem. Anal. 2011, 22, 555-563.

241. Hurst, W.J.; Stanley, B.; Glinski, J.A.; Davey, M.; Payne, M.J.; Stuart, D.A. Characterization of primary standards for use in the HPLC analysis of the procyanidin content of cocoa and chocolate containing products. Molecules 2009, 14, 4136-4146.

242. Barros , L.; Dueñas, M.; Ferreira, I.C.F.R.; Baptista, P.; Santos-Buelga, C. Phenolic acids determination by HPLC-DAD-ESI/MS in sixteen different Portuguese wild mushrooms species. Food. Chem. Toxicol. 2009, 47, 1076-1079.

243. Kalili, K.M.; de Villiers, A. Off-line comprehensive 2-dimensional hydrophilic interaction $\times$ reversed phase liquid chromatography analysis of procyanidins. J. Chromatogr. A 2009, 1216, 6274-6284.

244. Luthria, D.L.; Pastor-Corrales, M.A. Phenolic acids content of fifteen dry edible bean (Phaseolus vulgaris L.) varieties. J. Food Compos. Anal. 2006, 19, 205-211.

245. Colon, M.; Nerin, C. Role of catechins in the antioxidant capacity of an active film containing green tea, green coffee, and grapefruit extracts. J. Agric. Food Chem. 2012, 60, 9842-9849. 
246. Antolovich, M.; Prenzler, P.; Robards, K.; Ryan, D. Sample preparation in the determination of phenolic compounds in fruits. Analyst 2000, 125, 989-1009.

247. Silva, E.M.; Pompeu, D.R.; Larondelle, Y.; Rogez, H. Optimisation of the adsorption of polyphenols from Inga edulis leaves on macroporous resins using an experimental design methodology. Sep. Purif. Technol. 2007, 53, 274-280.

248. Li, P.; Wang, Y.; Ma, R.; Zhang, X. Separation of tea polyphenol from green tea leaves by a combined CATUFM-adsorption resin process. J. Food Eng. 2005, 67, 253-260.

249. Scordino, M.; Di Muaro, A.; Passerini, A.; Maccarone, E. Adsorption of flavonoids on resins: cyanidin 3-glucoside. J. Agric. Food Chem. 2004, 52, 1965-1972.

250. Rostagno, M.A.; Palma, M.; Barroso, C.G. Solid-phase extraction of soy isoflavones. J. Chromatogr. A 2005, 1076, 110-117.

251. Michalkiewicz, A.; Biesaga, M.; Pyrzynska, K. Solid-phase extraction procedure for determination of phenolic acids and some flavonols in honey. J. Chromatogr. A 2008, 1187, $18-24$.

252. Reichelt, K.V.; Peter, R.; Paetz, S.; Roloff, M.; Ley, J.P.; Krammer, G.E.; Engel, K.H. Characterization of flavor modulating effects in complex mixtures via high temperature liquid chromatography. J. Agric. Food Chem. 2010, 58, 458-464.

253. Cooper, K.A.; Campos-Gimenez, E.; Jimenez-Alvarez, D.; Nagy, K.; Donovan, J.L.; Williamson, G. Rapid reversed phase ultra-performance liquid chromatography analysis of the major cocoa polyphenols and inter-relationships of their concentrations in chocolate. J. Agric. Food Chem. 2007, 55, 2841-2847.

254. Takenaka, Y.; Morimoto, N.; Hamada, N.; Tanahashi, T. Phenolic compounds from the cultured mycobionts of Graphis proserpens. Phytochemistry 2011, 72, 1431-1435.

255. Lopes-Lutz, D.; Dettmann, J.; Nimalaratne, C.; Schieber, A. Characterization and quantification of polyphenols in Amazon grape (Pourouma cecropiifolia Martius). Molecules 2010, 15, 8543-8552.

256. Klejdus, B.; Vacek, J.; Benesova, L.; Kopecky, J.; Lapcik, O.; Kuban, V. Rapid-resolution HPLC with spectrometric detection for the determination and identification of isoflavones in soy preparations and plant extracts. Anal. Bioanal. Chem. 2007, 389, 2277-2285.

257. Churchwell, M.I.; Twaddle, N.C.; Meeker, L.R.; Doerge, D.R. Improving LC-MS sensitivity through increases in chromatographic performance: Comparisons of UPLC-ES/MS/MS to HPLC-ES/MS/MS. J. Chromatogr. B 2005, 825, 134-143.

258. Cavaliere, C.; Foglia, P.; Gubbiotti, R.; Sacchetti, P.; Samperi, R.; Lagana , A. Rapid-resolution liquid chromatography/mass spectrometry for determination and quantitation of polyphenols in grape berries. Rapid Commun. Mass Spectrom. 2008, 22, 3089-3099.

259. Roggero, J.-P.; Archier, P.; Coen, S. Chromatography of Phenolics in Wine. In Wine: Nutritional and Therapeutic Benefits; American Chemical Society: Washington, DC, USA, 1997; pp. 6-11.

260. de Villiers, A.; Kalili, K.M.; Malan, M.; Roodman, J. Improving HPLC separation of polyphenols. LCGC Eur. 2010, 23, 466-478.

261. Cicchetti, E.; Chaintreau, A. Comparison of extraction techniques and modeling of accelerated solvent extraction for the authentication of natural vanilla flavors. J. Sep. Sci. 2009, 32, 3043-3052. 
262. Selvaggini, R.; Servili, M.; Urbani, S.; Esposto, S.; Taticchi, A.; Montedoro, G. Evaluation of phenolic compounds in virgin olive oil by direct injection in high-performance liquid chromatography with fluorometric detection. J. Agric. Food Chem. 2006, 54, 2832-2838.

263. Kraushofer, T.; Sontag, G. Determination of some phenolic compounds in flax seed and nettle roots by HPLC with coulometric electrode array detection. Eur. Food Res. Technol. 2002, 215, 529-533.

264. de Pascual-Teresa, S.; Treutter, D.; Rivas-Gonzalo, J.C.; Santos-Buelga, C. Analysis of flavanols in beverages by high-performance liquid chromatography with chemical reactionm detection. J. Agric. Food Chem. 1998, 46, 4209-4213.

265. Oh, Y.S.; Lee, J.H.; Yoon, S.H.; Oh, C.H.; Choi, D.S.; Choe, E.; Jung, M.Y. Characterization and quantification of anthocyanins in grape juices obtained from the grapes cultivated in Korea by HPLC/DAD, HPLC/MS, and HPLC/MS/MS. J. Food Sci. 2008, 73, 378-389.

266. Moze, S.; Polak, T.; Gasperlin, L.; Koron, D.; Vanzo, A.; Poklar Ulrih, N.; Abram, V. Phenolics in Slovenian bilberries (Vaccinium myrtillus L.) and blueberries (Vaccinium corymbosum L.). J. Agric. Food Chem. 2011, 59, 6998-7004.

267. do Amaral, F.P.; Napolitano, A.; Masullo, M.; dos Santos, L.C.; Festa, M.; Vilegas, W.; Pizza, C.; Piacente, S. HPLC-ESIMSn profiling, isolation, structural elucidation, and evaluation of the antioxidant potential of phenolics from Paepalanthus geniculatus. J. Nat. Prod. 2012, 75, $547-556$.

268. Zhang, L.; Chen , J.; Wang, Y.; Wu, D.; Xu, M. Phenolic extracts from Acacia mangium bark and their antioxidant activities. Molecules 2010, 15, 3567-3577.

269. Wei, S.-D.; Zhou, H.-C.; Lin, Y.-M.; Liao, M.-M.; Chai, W.-M. MALDI-TOF MS analysis of condensed tannins with potent antioxidant activity from the leaf, stem bark and root bark of Acacia confuse. Molecules 2010, 15, 4369-4381.

270. Edenharder, R.; Keller, G.; Platt, K.L.; Unger, K.K. Isolation and characterization of structurally novel antimutagenic flavonoids from spinach (Spinacia oleracea). J. Agric. Food Chem. 2001, 49, 2767-2773.

271. Bianco, A.; Buiarclli, F.; Cartoni, G.; Coccioli, F.; Muzzalupo, I.; Polidor, A.; Uccella, N. Analysis by HPLC-MS-MS of Biophenolics in olives and oils. Anal. Lett. 2001, 34, 1033-1051.

272. Chinnici, F.; Natall, N.; Spinabelli, U.; Riponi, C. Presence of polycyclic aromatic hydrocarbons in woody chips used as adjuvant in wines, vinegars and distillates. LWT-Food Sci. Technol. 2007, 40, 1587-1592.

273. Muanda, F.N.; Soulimani, R.; Dicko, A. Study on biological activities and chemical composition of extracts from Desmodium adscendens leaves. J. Nat. Prod. 2011, 4, 100-107.

274. Pawlowska, A.M.; Oleszek, W.; Braca, A. Quali-quantitative analyses of flavonoids of Morus nigra L. and Morus alba L. (Moraceae) fruits. J. Agric. Food Chem. 2008, 56, 3377-3380.

275. Jandera, P. Stationary phases for hydrophilic interaction chromatography, their characterization and implementation into multidimensional chromatography concepts. J. Sep Sci. 2008, 31, 1421-1437.

276. Zeng, J.; Zhang, X.; Guo, Z.; Feng, J.; Zeng, J.; Xue, X.; Liang, X. Separation and identification of flavonoids from complex samples using off-line two-dimensional liquid chromatography tandem mass spectrometry. J. Chromatogr. A 2012, 1220, 50-56. 
277. Liang, Z.; Li, K.; Wang, X.; Ke, Y.; Jin, Y.; Liang, X. Combination of off-line two-dimensional hydrophilic interaction liquid chromatography for polar fraction and two-dimensional hydrophilic interaction liquid chromatographyxreversed-phase liquid chromatography for medium-polar fraction in a traditional Chinese medicine. J. Chromatogr. A 2012, 1224, 61-69.

278. Roberts, E.A.H.; Wood, D.J. A study of the polyphenols in tea leaf by paper chromatography. Biochem. J. 1951, 49, 414-422.

279. Nambiar, V.S.; Daniel, M.; Guin , P. Characterization of polyphenols from Coriander leaves (Coriandrum sativum), red Amaranthus (A. paniculatus) and green Amaranthus (A. frumetaceus) using paper chromatography: and their health implications. J. Herb Medic. Toxicol. 2010, 4, 173-177.

280. Sajewicz, M.; Staszek, D.; Waksmundzka-Hajnos, M.; Kowalska, T. Comparison of TLC and HPLC fingerprints of phenolic acids and flavonoids fractions derived frome selected Sage (Salvia) species. J. Liq. Chrom. Rel. Technol. 2012, 35, 1388-1403.

281. de Oliveira, C.B.; Comunello, L.N.; Lunardelli, A.; Amaral, R.H.; Pires, M.G.S.; da Silva, G.L.; Manfredini, V.; Vargas, C.R.; Gnoatto, S.C.B.; de Oliveira, J.R.; et al. Phenolic enriched extract of Baccharis trimera presents anti-inflammatory and antioxidant activities. Molecules 2012, 17, 1113-1123.

282. Cao, X.; Wang, C.; Pei, H.; Sun, B. Separation and identification of polyphenols in apple pomace by high-speed counter-current chromatography and high-performance liquid chromatography coupled with mass spectrometry. J. Chromatogr. A 2009, 1216, 4268-4274.

283. Yang, Y.; Gu, D.; Wu, H.; Aisa, H.; Zhang, T.; Ito, Y. Application of preparative high-speed countercurrent chromatography for separation of elatine from Delphinium shawurense. J. Liq. Chrom. Rel. Technol. 2008, 31, 3012-3019.

284. Ito, Y. Golden rules and pitfalls in selecting optimum conditions for high-speed counter current chromatography. J. Chromatogr. A 2005, 1065, 145-168.

285. Lu, H.-T.; Jiang, Y.; Chen, F. Application of preparative high-speed counter-current chromatography for separation of chlorogenic acid from Flos lonicerae. J. Chromatogr. A 2004, 1026, 185-190.

286. Yanagida, A.; Shoji, A.; Shibusawa, Y.; Shindo, H.; Tagashira, M.; Ikeda, M.; Ito, Y. Analytical separation of tea catechins and food-related polyphenols by high-speed counter-current chromatography. J. Chromatogr. A 2006, 1112, 195-201.

287. Wang, J.; Gao, H.; Zhao , J.; Wang, Q.; Zhou, L.; Han, J.; Yu, Z.; Yang, F. Preparative separation of phenolic compounds from Halimodendron halodendron by high-speed countercurrent chromatography. Molecules 2010, 15, 5998-6007.

288. He, D.; Gu, D.; Huang, Y.; Ayupbek, A.; Yang, Y.; Aisa, H.A.; Ito, Y. Separation and purification of phenolic acids and myricetin from black currant by high speed countercurrent chromatography. J. Liq. Chrom. Rel. Technol. 2009, 32, 3077-3088.

289. Caridi, D.; Trenerry, V.C.; Rochfort, S.; Duong, S.; Laugher, D.; Jones, R. Profiling and quantifying quercetin glucosides in onion (Allium cepa L.) varieties using capillary zone electrophoresis and high performance liquid chromatography. Food Chem. 2007, 105, 691-699.

290. Wang, S.C.; Zhang, Z.; He, L.C.; Li, H. Non-aqueous capillary electrophoresis for separation and simultaneous determination of magnoflorine, taspine, and caulophine in Caulophyllum robustum collected in different seasons. Anal. Lett. 2010, 43, 1534-1542. 
291. Liu, E.-H.; Qi, L.-W.; Cao, J.; Li, P.; Li, C.-Y.; Peng, Y.-B. Review: Advances of modern chromatographic and electrophoretic methods in separation and analysis of flavonoids. Molecules 2008, 13, 2521-2544.

292. Fonseca, F.N.; Tavares, M.F.M.; C, H. Capillary electrochromatography of selected phenolic compounds of Chamomilla recutita. J. Chromatogr. A 2007, 1154, 390-399.

293. Chen, X.J.; Ji, H.; Wang, Y.T.; Li, S.P. Simultaneous determination of seven flavonoids in Epimedium using pressurized liquid extraction and capillary electrochromatography. J. Sep. Sci. 2008, 31, 881-887.

294. Cheung, R.H.F.; Marriott, P.J.; Small, D.M. CE methods applied to the analysis of micronutrient in foods. Electrophoresis 2007, 28, 3390-3413.

295. Rybarczyk, A.; Pegg, R.B.; Amarowic, R.Z. Capillary zone electrophoresis (CZE) of flaxseed phenolic constituent- A short report. Pol. J. Food Nutr. Sci. 2008, 58, 263-267.

296. Wu, T.; Quan, Y.Q.; Ye, J.N. Determination of flavonoids and ascorbic acid in grapefruit peel and juice by capillary electrophoresis with electrochemical detection. Food Chem. 2007, 100, 1573-1579.

297. Zhang, S.; Dong, S.Q.; Chi, L.Z. Simultaneous determination of flavonoids in chrysanthemum by capillary zone electrophoresis with running buffer modifiers. Talanta 2008, 76, 780-784.

298. Yuan, G.; Liu, Y.; Li, T.; Wang, Y.; Sheng, Y.; Ming, G. Simultaneous and rapid determination of main lignans in different parts of Schisandra sphenanthera by micellar electrokinetic capillary chromatography. Molecules 2011, 16, 3713-3722.

299. Verardo , V.; Gomez-Caravaca, A.M.; Segura-Carretero, A.; Caboni, M.F.; Fernandez-Gutierrez, A. Development of a CE-ESI-microTOF-MS method for a rapid identification of phenolic compounds in buckwheat. Electrophoresis 2011, 32, 669-673.

300. Chester, T.L.; Pinkston, J.D.; Raynie, D.E. Supercritical fluid chromatography and extraction. Anal. Chem. 1994, 66, 106-130.

301. Miller, J.M. Chromatography: Concepts and Contrasts, 2nd ed.; John Wiley and Sons.: Hoboken, NJ, USA, 2004.

302. Bamba, T. Application of supercritical fluid chromatography to the analysis of hydrophobic metabolites. J. Sep. Sci. 2008, 31, 1274-1278.

303. Kamangerpour, A.; Ashraf-Khorassani, M.; Taylor, L.T.; McNair, H.M.; Chorida, L. Supercritical fluid chromatography of polyphenolic compounds in grape seed extract. Chromatographia 2002, 55, 417-421.

304. Liu, Z.; Zhao, S.; Wang, R. a.; Guanghua, Y. Separation of polyhydroxylflavonoids by packedcolumn supercritical fluid chromatography. J. Chromatogr. Sci. 1999, 37, 155-158.

305. Sun, S.Y.; Jiang, W.G.; Zhao, Y.P. Comparison of aromatic and phenolic compounds in cherry wines with different cherry cultivars by HS-SPME-GC-MS and HPLC. Int. J. Food Sci. Technol. 2012, 47, 100-106.

(C) 2013 by the authors; licensee MDPI, Basel, Switzerland. This article is an open access article distributed under the terms and conditions of the Creative Commons Attribution license (http://creativecommons.org/licenses/by/3.0/). 